The Geneva Papers on Risk and Insurance, 17 (No. 62, January 1992), 40-80

\title{
Aging and the Four Pillars in Japan
}

\author{
by Isao Shimowada*
}

\section{Demographic trends and the four pillars in Japan}

\subsection{Aging of population}

The most striking feature of demographic shift in Japan is the speed of aging of the population as well as high aging population ratio at the peak of the aging process. That is to say, Japan's population is aging at an unparalleled speed when compared with Western countries, and it is projected that, in the 21st century, Japan will become the most aged society ever seen in the West (Figure 1-1). For example, it took about 45-130 years, in Western countries, for the proportion of the people aged 65 and over to reach $14 \%$ of the total population starting from $7 \%$. In Japan, however, it will take only 25 years to increase from $7 \%(1970)$ to $14 \%(1995)$ (Table 1-1). The number of people aged 65 or over in Japan was 12.5 million (10.3\% of the total) in 1985 , but it will be 21.34 million $(16.3 \%)$ in 2000 , and reach 31.88 million (23.6\%) at the estimated peak of the aging process in 2020 (Table 1-2). This means that almost one fourth of all people will be elderly citizens, which is the highest figure so far projected in the world (Table 1-3). Furthermore, advanced elderly citizens (aged 75 years and above) are also expected to increase rapidly.

Aging population signifies that the dependency ratio of aged population, or the proportion of elderly people aged 65 and over to working age population (the age group 15 to 64) is increasing (for this trend, see Table 1-2: "dependency ratio of aged population"). This is causing serious financial problems in public pension schemes which are based on a contract between new and old generations. The average life expectancy of Japanese people has also increased dramatically after the war. It was 50 years for men and 54 years for women in 1947, but after 40 years and because of a drastic drop in the mortality rate during these years, this figure rose to 75 years for men and more than 80 years for women in 1985, and now Japan is the number one longevity country in the world (Figure 1-2, 1-3).

Naturally, the social situation cannot be the same as some 30 years ago, when the average life expectancy was around 60 . Now it is a matter of serious concern to individuals as well as society to maintain income security for a long period of about 20 years after retirement at age 60 . Family structure is also changing; the number of families composed

\footnotetext{
${ }^{*}$ Professor at the Faculty of Commerce, Hitotsubashi University, Japan.
} 
of three generations is decreasing from year to year, while families of an older couple or of a single person are rapidly increasing (Table $1-4$ ). Building up a new socio-economic system well suited to the "era of 80 years' life span" has now become an urgent task to be tackled by many quarters of society.

With the arrival of a full-scale longevity society, it is now an immediate problem to establish good plans preparing for a rapid increase of aged people who need special nursing care, including aged people suffering from senile dementia or bed-confined elderly. However, the proportion of the aged requiring special care to the total elderly population is about $5 \%$; most of the aged can live a healthy daily life. These "new old" who are mentally and physically healthy and active as well as have some degree of financial means will increase from now on, and measures for them will become more and more important. Such measures should include employment policies for older workers in addition to other policies covering various social aspects.

An unexpected drop in birth rate, together with a decline in mortality rate, has accelerated the aging process of the population in Japan. Total fertility rate in Japan was recorded at 1.57 in 1989, which was the lowest in history and was already reported as " 1.57 shock" by the media (Fig. 1-4, Table 1-5). This rate further dropped to 1.53 in 1990. Factors contributing to this phenomenon include a rise of the rate in the unmarried, trends of late marriage, a decrease in the number of children a couple has in their lives, and delay in timing of the birth cycle and so on. The recent drop in birth rate is said to be caused by a rise in the rate of the unmarried within the age group 20 to 30 due to the trend of late marriage (Table 1-6).

When a birth rate remains at such a low level in a society of accelerated aging, the proportion of working age population to the total population will drop significantly in the future, resulting in tremendous impacts on industrial structures, the labor market and the consumer market and so on. A sharp increase of social security costs cannot be avoided either.

\subsection{Changes of the four pillars after the war}

The analysis of development of the four pillars of income security after the war-laying stress on the development of social security (1st pillar) - enables us to distinguish four periods in this development: reconstruction after the war; high growth of economy; stable growth of economy; and self-sustained growth and expansion.

a) The period of reconstruction after the war

The first period (1945 to 1960) includes the time of utter confusion of the Japanese economy immediately after the war, up to the days when Japan set its economy on its way. Public pension schemes were newly created and improved in this period. With the National Pension Law being enforced in 1959, everyone could participate in one of the seven public pension schemes, and the so-called "universal social security pension coverage" system was established. However, because of immaturity of the schemes as well as the very low level of benefits, these public pension schemes failed to function as an income security system. In addition, advance of urbanization and the nuclear family phenomenon impaired co-support ability within a family, and people had to defend themselves with intensified self-help efforts through savings and buying insurance products (3rd and 4th pillars). Corporate or occupational pension plans (2nd pillar) were established in a very limited number of 
enterprises at this stage, and retirement allowance (payment in lump sum) systems were introduced by many companies as a system to replace Employees' Pension scheme which stopped functioning because of inflation. In this situation, life insurance companies which restarted their operations after the war with sales of monthly premium insurance of small sums, rapidly recovered from the damage of the war. This was realized due to a rise in personal net income and through managerial efforts including employment of many female sales agents in the industry, and the companies enjoyed favorable growth from 1950. They soon came back to the pre-war level, in terms of business in force, in 1958. In 1963, the ratio of life insurance in force to national income reached $95.1 \%$, the figure well exceeding $88 \%$, which was the average from 1934 to 1936 . An unusually high savings rate and a high participation rate of older people in the work force, also to be seen in later periods in Japan, basically grew out of the situation during this period.

b) The period of high economic growth (1960-73)

Backed by a rapidly growing economy, the government adopted an aggregate pension system (where the social insurance periods accumulated in the different public pension schemes are added up) and implemented a significant increase of pension benefits. Thus public pension schemes (1st pillar) started to fulfill their original function. The year 1973 is sometimes called the "year of pension" because benefit levels were greatly raised and an automatic price-index adjustment system was introduced at this time in a setting of rapidly aging population and of change in people's attitude toward supporting elderly persons. As a result of indexation, real value of pension payment was maintained automatically against economic fluctuation, and about $60 \%$ of the current average standard wage was paid as old age pension in the Employees' Pension scheme.

Corporate or occupational pension plans (2nd pillar) were adopted by many companies during this period. Because of a rapid increase of retirement allowance due to an increase of aged workers and yearly wage hikes, enterprises in particular felt the necessity to introduce a corporate pension plan with preferential tax treatment, the kind of plan implemented in Western countries. Such necessity was met in 1962 with the establishment of a qualified retirement pension system. Also, as a result of amendment of the Employees' Pension Insurance Act in 1965, the Employees' Pension fund system (so-called adjusted pension system) started in October 1966. This system allows a public pension insurance plan to be combined with a private enterprise pension plan and allows that part of contribution in proportion to income of public pension plan to replace a private pension plan. The system was initiated to reduce the costs of enterprises in the plan which were increasing as a result of the improvement of Employees' Pension benefits.

These two systems which compose the corporate pension system in Japan were adopted at this time by many companies. However, inflation occurred yearly in this period. In addition, many enterprises set the working age limit at 55 while payment of pension benefits started at age 60 . These factors prompted many retiring employees to get their pension in a qualified plan in the form of lump sum payment, not as a pension, so that they could use the money for living expenses or for repayment of their housing loan.

Even though the 1st and the 2nd pillars began to fulfill the original functions assigned to them, they were still at an introduction/improvement stage and the importance of these two pillars was not very high as income security sources for many elderly persons. According to a survey conducted by the Prime Minister's Office in 1972, about $70 \%$ to $90 \%$ of older persons (aged 65 and over) received social security benefits in Western countries, 
followed by those who got property income and then those receiving earned income, while in the case of Japan about $75 \%$ of older persons (aged 60 and over) had earned income, followed by those who got income transferred from their children. The number of older people who relied on social security income was only in third place (cf. Management and Coordination Agency, "White Paper on National Life; 1974 Edition” pp. 189-191).

This means that the 4th pillar was still very important as well as the 3rd pillar, given the fact that the household savings rate was at a very high level internationally even during inflation. Life insurance companies, throughout the period, experienced the same high growth as before, with their ratio of its business in force to national income rapidly rising each year to $168 \%$ in 1973 , which was the highest level in the world, jumping from the rank of 3rd in the previous year. Life insurance in force per head amounted to $¥ 1.37$ million in the same year, which was the 3rd highest in the world, behind only the United States and Canada.

c) The period of stable growth (1973-1986)

It was just when an indexation system was introduced and public pension schemes were going to mature and their original function as an income security means was about to be fulfilled, that an oil shock hit Japan. The Japanese economy had to shift to a lower line of growth. In addition, aging of the population was close at hand. These conditions highlighted the problem of financing social security and promoted total re-examination of the system including public pension schemes. The government raised benefit levels based on indexation on one hand, but on the other hand contribution rates were also increased in order to solve the problem of financing the schemes. For instance, the contribution rate for Employees' Pension Insurance was gradually raised from $6.4 \%$ in 1973 and almost doubled to $12.4 \%$ in October 1985 (Table 1-7).

Another long-pending problem was how to abolish the differentials among seven public pension schemes which started after the war. This problem was settled in 1985, when the idea of a basic pension system was introduced, which greatly reformed these pension schemes in order to prepare for the approaching problem of serious aging of the population and to maintain impartiality of benefits within a generation as well as among generations on the basis of stable and long-term management of the public pension system in Japan. (This reform was enforced in April 1986).

While the social security system was being reviewed, the government and business circles carried on a big campaign to emphasize the importance of self-help efforts. Trade unions also shifted their priority from demanding the expansion of the social security system to employees' welfare improvement such as expansion of the corporate pension plans. Assets of corporate pension plans rapidly increased in this period and life insurance companies and trust banks entered into keen competition to be appointed as fiduciary of such assets. These companies expected that this corporate pension market would rapidly grow in the future. Other financial institutions, motivated by the same expectation, also wanted to participate in this market.

Anxiety about the future of public pension schemes as well as of one's own old age, was giving people, housewives in particular, a growing interest in individual annuities, and the number of persons who bought this type of insurance policy was sharply increasing from about 1975. In order to cope with this trend, life insurance companies and other financial institutions introduced new products in this field one after the other. The government also 
adopted a policy to promote such self-help efforts and framed the so-called "tax exemption system on wage earners' property accumulation" system in 1982. Partial amendment of the Income Tax Act in 1984 created a system of tax exemption on premiums for individual annuity insurance, which allowed deductions from income of up to $¥ 5,000$ for income tax and $¥ 3,500$ for the resident’s tax. (The limit of these deductible amounts was increased to $¥ 50,000$ and $¥ 35,000$ respectively in April 1990.)

Given the growing strength of self-help efforts among the four pillars, life insurance companies further improved their performance even under the low growth economy. Japan took the top position in the world for the first time in 1987 in terms of "life insurance in force", the "ratio of life insurance in force to national income" and the "average amount insured per capita".

In the circumstance of aging of the population, shortage of workforce and re-examination of public pension schemes, a tendency toward flexibility in retirement age, which had usually been set at 55 , or extending that age, developed and companies which started to set the age limit at 60 were on the increase.

In 1986, the "Law Concerning the Stabilization of Employment for Older.Workers" and the "Equal Employment Opportunity Law" were enforced in order to prepare for a favorable environment for the employment of older people, to ensure equal opportunity of employment for female workers and to prohibit discriminative treatment of female workers. These moves suggested that increasing weight would be put on the fourth pillar in the future.

As we have seen, emphasis placed on the four pillars was gradually changed among them after the oil shock with the aging of the population as well as with the shifting from a high to a low growth economy. We can summarize the characteristics of the decade of the 1970 's as "a transition period from expansion of social security to re-examination of the system", and the decade of the 1980's as "a transition period from re-examination of social security to giving priority to collective security within companies and individual security". Then, the characteristic feature of the present and the 1990's may be dubbed "groping period for balance among the four pillars, including pillar of employment". In the next chapter I will try to explain the recent trend which composes the "fourth period of selfsustained growth and expansion" (from 1986 on).

\section{Recent trends in the period of self-sustained growth and expansion = groping period for measures in the society with an aging population}

\subsection{Recent reforms of public pension schemes}

According to the "Basic Survey on National Life" in 1989, the average amount of benefits from public pension schemes per household headed by aged person(s) was $¥ 1,363,000$, which accounted for about $49,4 \%$ of total income of the household. About half $(49.2 \%)$ of those households which were headed by aged person(s) and receiving public pension benefits made a living only on such pension benefits. In $70.2 \%$ of these households, public pension benefits accounted for a considerable part $-60 \%$ or more - of their income. (cf. "White Paper on Health and Welfare: 1990 Edition" by Ministry of Health and Welfare p. 161). Answering the question; "By what means do you pay the cost of living in your old age?" in the survey, $86.4 \%$ referred to public pension benefits (Figure 2-1 (B)). Public pension schemes have now become the main source of livelihood in one's old age. Among 
social security benefits, public pension benefits have rapidly increased in importance. In 1980 , they equaled medical benefits which had been the top item in the social security system for a long time. And then they greatly exceeded medical benefits and accounted for more than $50 \%$ of the total social security benefit payment in 1988 (Figure 2-2). The benefit level of employees' pension scheme in Japan has also risen to the same, or even higher level as that practiced in major developed countries in the West (Table 2-1). Now, in preparing for a society of the 21 st century, the positioning of the public pension system in our economy and its control has become a very important task for us.

a) Introduction of basic pension

The public pension system in Japan developed mainly after the war was divided into seven schemes. (The oldest of these schemes, "Non occupational pension scheme" of Seamen's Insurance, which was introduced in 1939, was combined with Employees' Pension Insurance in 1985, so that now we have six schemes as is shown in Table 2-2). The National Pension schemes and Employees' Pension schemes are the largest ones, to which about $90 \%$ of the total of the insured belong. Because each scheme is different in its purpose, history, and level of maturity from the others, there were many inherent problems in the system such as: (1) differentials among schemes, (2) problems of excessive or overlapping payment of benefits, (3) instability of financial bases caused by changes of employment/ industry structures, and so on. These elements prompted the government to make a significant reform covering all aspects of public pension systems in 1985. This was the first stage in unifying all public pension schemes and the main points of the reform were as follows:

(1) With the introduction of the basic pension system in April 1986, the system was restructured (Figure 2-3), and there were structural changes in pension programmes. Now the National Pension System will provide basic pensions generally to all people insured while other schemes such as Employees' Pension scheme, and National Public Services Mutual Aid Association Pension scheme will provide, in principle, "additional benefits" in proportion to the insured's income. The whole structure may be called a "two-story" system.

(2) Benefit rates will gradually be reduced over a twenty-year period from now in order to lighten the burden of contributions at the coming "peak period". An estimated prediction is that in the case of Employees' Pension, the contribution rates at the peak period will be reduced to $28.9 \%$ by this change from $38.8 \%$ when there was no change. (cf. "Trend of Insurance and Pension; Indicators of Welfare.. Special Issue", Vol. 37, No. 14,1990, p. 43). It is further predicted that if the pension age is raised to 65 from 60 , as under the current system, the contribution rates would be $26.1 \%$ at the peak period (Figure 2-4).

(3) The reform stipulated compulsory inclusion of home-workers such as housewives in the system, whose participation had been voluntary before. The aim was to sort out the mess of women's pension coverage and to establish their right to pension. This reform allowed all insured people, including wives of salaried workers, to receive a basic pension in his/her own name without requiring them to pay a separate contribution; it was included in their husband's (or other supporter's) contribution to the employees' pension schemes.

Students aged 20 or over, whose participation in the scheme had also been optional before, have been required since April 1991 to participate in the basic pension scheme and to pay their contribution. 
At a cabinet meeting in 1984, it was decided that employees' pension, which is divided into five schemes centering around employees' pension scheme at present, should be unified by 1995 as a temporary target date, but now such unification is likely to be delayed.

b) Introduction of National Pension Fund

Based on the reform of 1989, a new National Pension Fund was established in April 1991. In order to prepare for the arrival of a full-scale longevity society, this fund is designed to cope with various orderly life plans of self-employed people, paying special attention toward realizing the fair treatment of them compared to the group of salaried workers who will get additional pension over and above the common basic pension. Namely, selfemployed people are allowed to join additional national pension schemes (Figure 2-5). However, the system has such problems as: (1) entry to this additional scheme is optional; (2) setting of the amount of contribution and of pension is also highly optional and, as a result, large income earners are treated more favorably.

c) Dispute on the raising of the pension age to 65

The proposal to raise the pension age from 60 (current system) to 65 (in line with Western countries) for public pension schemes other than National Pensions has been carefully examined, considering its relation to retirement age, which is now set at 55 to 60 by most companies in Japan. The government proposed, in its 1989 draft of the reform bill, that the pension age for men will be raised to 61 in 1998 and be raised by one year every three years after that, eventually reaching 65 in the year 2010 . The pension age for women is proposed to be 61 in 2003, and to be raised in the same way as for men, reaching 65 in 2015. This proposal of the time schedule was amended, however, by the Diet. It was decided that, at the time of the next re-calculation of financial issues in 1994, the schedule should be re-examined and be enacted into law, giving overall consideration to the future perspective of employees' pension financing, the situation of promotional measures to secure employment for aged people, and the level of benefit rates as well as a better way to finance their costs.

It should be added that, in 1965, the employees' pension scheme introduced a program of payment of old-age pensions to those in actual service. This program has experienced several reforms. As of December 1989, benefit rates of old-age pensions for employed persons aged 60 to 64 are classified into 7 levels according to the beneficiaries' standard monthly remuneration; and about 20 to $80 \%$ of the usual benefit amount is cut from the payment. For those working people aged 65 and over, the full amount is paid if their monthly remuneration is at a certain level or below, and $20 \%$ will be cut for those with income above that level (Table 2-3). Old-age basic pensions can also be paid in reduced amount for those aged below 65 (reduced pensions) or in increased amount for those aged 65 and over (increased pensions).

\subsection{Increasing importance of corporate pensions}

Corporate pension schemes in Japan are mainly based on employees' pension funds and qualified retirement pension schemes (both introduced in the 1960's), which rapidly spread in the 1970's backed by tax benefits of both systems, further aging of employees, and the reviewing process of public pension schemes. Thus corporate pensions have become more an important form of pension plan in Japan.

As of March 1990, the number of persons insured by these systems is 9.05 million for qualified schemes and 9.03 million for employees' pension funds. However, as some 
companies adopt both schemes, about one against every two persons insured by employees' pension fund is covered by a corporate pension scheme when overlapping figures are adjusted. Adoption rate of the two schemes is rising every year; the rate of adoption was $26 \%$ for qualified pension and $24 \%$ for employees' pension funds according to a JILI (Japan Institute of Life Insurance) survey conducted in 1989 (Figures 2-6, 2-7).

The balance of assets is also rapidly increasing, recording $¥ 11,900$ billion for qualified schemes and $¥ 22,500$ billion for employees’ pension funds, totalling $¥ 34,400$ billion altogether. As to the reasons for adopting these schemes, most companies referred to the merits of "tax incentive" and "allowance cost for retirement is levelled" (Table 2-4).

Although remarkable institutional improvements have not been implemented recently, the 1988 amendment of the Employees' Pension Insurance Act achieved several improvements such as those concerning an aggregate pension system, creation of pension benefit guarantee business, introduction of joint business processing systems for small-size funds, and creation of an actuary system for pensions. In April 1989, requirements for authorizing establishment of an employee's pension fund were relaxed in terms of the number of insured persons, creation of regional type of funds, and so on.

It should be pointed out that employees also place high hopes on the corporate pensions. According to a recent survey on employees' opinions conducted by JILI, next to the remuneration issue, the largest number of complaints is concentrated on the present situation of corporate pensions. They want further improvement of the system to be made (Figure 2-8). Another survey of JILI conducted on companies, also reveals that many companies pointed out the problem of the current corporate pensions of low levels of benefits (Tables 2-5, 2-6). This means that increasing numbers of companies, large-sized ones in particular, want to raise pension levels.

\subsection{The effects of demographic trends on savings and private insurance}

It is well known that the household savings rate in Japan has been ranked high among developed countries as is shown on Figure 2-9. However, a long-term trend shows that the rate has been decreasing throughout the years. Some analysts try to connect this phenomenon with the aging of the population, but such a correlation is not so clear. On the contrary, when asked about the purpose of savings, the percentage of people who refer to the "necessity of securing living expenses for old age" has been rising (Table 2-7). When one considers the fact that the number of people aged fifty or over, who are strongly aware of such a necessity, is rapidly increasing, and that the savings rates of households headed by olderly persons are actually high (Figure 2-10), we should expect that the savings rate in Japan will remain high for some time hereafter.

In a situation of financial deregulation and householders' acute preference for financial products with higher interest rates due to their increasing assets, the weight of assets held in the form of securities among household savings is increasing while that of cash deposits is decreasing. On the other hand, the proportion of life and non-life insurance policies.in household assets tends to be expanding. Looking at the figures for the assets held by various financial institutions, the ratio of life insurance funds to the aggregate value held by all the financial institutions is steadily growing and reached $9.1 \%$ at the end of March 1990 . The bank share of the total funds are, on the other hand, decreasing in the long run. 
The main products of life insurance have changed several times; from "endowment" which had been the leading product since prewar days, to "endowment-with-term" in the 1960's which became popular due to increasing cases of traffic accidents and other reasons, to "short term single premium endowment" after the oil shock of 1973, which was well accepted for its tax-saving and high return nature (Figure 2-11). On the whole, diversification of life insurance products has continued, but among others, a sharp increase has been recorded since 1975 for products that reflect the needs of an aging society such as individual annuities, whole life, term-with whole life, and group pension insurance.

Individual annuities, in particular, increased very rapidly in the 1980's (Figure 2-12). According to a survey conducted by JILI in 1989, the ownership rates of these products reached $10 \%$, with male high income group accounts for $22 \%$, and $18 \%$ for women of the same group. (cf. "Individual Survey on Life Security and Life Insurance", pp. 48-49). It is expected that, in the future, products for individual annuities will further increase as a result of the introduction and expansion of the tax incentive measures which were started in 1984 and renewed in 1990. Life Insurance companies are actively trying to meet the needs of an aging society by making investments in businesses such as "homes for the aged" (either independently or as a joint venture) as well as by developing new products such as "nursing care insurance".

\subsection{Effects of demographic trends on employment}

In Japan, primary industries related to agriculture, forestry and fishery played a principal role in the economy of post-war days until about 1955. After that, however, rapid industrialization, centering around heavy industrial and chemical products, was achieved and led to a period of high economic growth. This very swift economic development brought about a sudden change in the social structure. The change came about for many reasons; the flow of the labor force from rural to urban regions led to an advancement in urbanization (Figure $2-13$ ); there was an expansion of salaried classes in the society (Figure 2-14), an increase in "nuclear families", and a rise in the rate of graduates entering higher grade schools (Figure $2-15)$. In 1955 primary industries accounted for $37.6 \%$ of the total employed work force, but the figure sharply fell to $23.5 \%$ in 1965 , while the percentage of the employed work force for secondary industries rose from $24.4 \%$ to $31.9 \%$ and tertiary industries from $38.1 \%$ to $44.6 \%$ in the same period. Following such a change in the industrial structure, the percentage of employees in the total employed people including those self-employed rose from less than $40 \%$ in 1950 to $60.8 \%$ in 1965 , pushing Japan into being a society of salaried workers. This transformation of the industrial and employment structures further continued, resulting in a decrease of people employed in the primary industries every year. This trend also showed a decrease in the number of work force engaged in the secondary industries, only those engaged in the tertiary industries increased. The percentage of people engaged in the tertiary industry accounted for $54.5 \%$ in 1980 , increased to $58.2 \%$ in 1989 and is expected to reach $62 \%$ by the year 2000 (Table 2-8). In this expansion of the service industry in Japan, a steady increase of people employed in the food service industry and in the retail business has been recorded. More recently, services geared towards business establishments such as providing information, as well as medical services for individual people, have also been expanding. In the future, following a further expansion of the service industry and the growing role of software in the economy, it is expected that the number of people engaged in professional or technological work will increase as well as those in clerical work. 
Since the oil shock, specifically in the 1980's, service industries have experienced accelerating growth in the whole of the economy, while the Japanese economy itself steadily developed into a sustainable expansion period after a stable growth period. Much improvement has also been seen in the employment situation. The ratio of effective labor demand to effective supply exceeded $100 \%$ in June 1988 . The Japanese economy has been undergoing "softmization" and technical sophistication, as well as a shift from export-orientated industries to placing more emphasis on domestic demands. This move prompted a big change in the labor market, including a "mismatching" between labor demand and supply, and a sharp shortage of workers against increasing demand in the labor market. A change in the age composition of the population also affected this trend. Shortage of labor is especially striking in the construction and manufacturing industries, and it causes serious problems for small sized enterprises in this sector. According to a recent survey, about $40 \%$ of middle- and small-sized companies cited difficulty of employment as the biggest problem for the management of their business (Table 2-9). If the birth rate remains as low as its present level, the labor force in Japan is expected to decrease at the beginning of the 21st century, and it is predicted that the period of labor shortage will continue over a long period of time.

Two very important laws for increasing aged workers and female workers, that is, the "Law Concerning the Stabilization of Employment for Older Workers" and the "Equal Employment Opportunity Law", were put into force in 1986. The latter law aims to promote the employees' of female workers and to arrange an "easy-to-work" environment for them through equal opportunity and equal treatment of male and female workers in employment. Such a measure was prompted by a rise in the female employment rate as well as a rise in the ratio of female graduates from universities. The former law was designed: to allow the government to take some administrative action against companies which do not adopt a retirement system with the age limit set at 60 ; to encourage companies to have a more extended retirement age system, re-employment after retirement and other continued employment measures, as well as to support companies' efforts to give preparatory education for retiring workers; to give various incentives and subsidies to companies who want to employ workers aged 60 or over, or who want to train middle and old-aged workers; to support so-called "Silver Human Resource Centers" which would help elderly people to find part-time and temporary jobs. Furthermore, the government has also actively engaged in, since the latter half of the 1980's, various operations and implemented measures in relation to continued employment, new opportunity of employment, or the development of skills, for older workers.

For a long time after the war, many companies in Japan adopted a system of retirement age set uniformly at 55 (Figure 2-16), but the pension age of public pension schemes started only at 60 (employees' pension) or at 65 (national pension). This gap was a serious problem, and a rapid expansion of the average life span of Japanese people demanded an extended retirement at a later stage of life. Prompted by the Law concerning the Stabilization of Employment for Older Workers in 1986 and by the phenomenon of labor shortage, companies are now gradually adopting a system of setting an age limit at 60 (Figure 2-16, Table 2-10).

There is a proposal to gradually raise the pension age to 65 (for employees' pension). However, now very few companies $(4 \%)$ have a system for retirement over the age of 60 (Table 2-10, Table 2-11), and prompt adoption of such a system by companies is required 
as a preliminary step to raise the pension age. A recent survey by JILI shows that employed persons mostly want their company to extend the age limit if the pension age for employees' pension is raised to 65 . The next thing they would want from their company in such a situation is "help finding employment in other places" and "a system for re-employment" (Figure 2-17). An investigation committee of the Ministry of Labor also proposes: (1) there is a necessity to promote measures for continued employment including extension of age limit up to 65 , re-employment after retirement, and so on, (2) as the first step to realize this, the age limit of 60 should be firmly established by 1993, (3) it is necessary to prepare an "easyto-work" environment for elderly workers and to establish measures for health control and for helping the development of job ability for elderly workers, (4) to enrich the operations of the "Silver Human Resource Centers". ("To cope with labor shortage - Report of the Committee to find better employment policy dealing with the structural change of the labor market" edited by the Employment Security Bureau, Ministry of Labor, 1991, p. 17). In March 1990, the Employment Council of the same ministry also submitted a report proposing an amendment to the Law Concerning the Stabilization of Employment for Older Workers, which would require enterprises to secure continued employment up to age 65 .

According to an $\mathrm{OECD}$ research report, the labor force participation rate for elderly people in Japan ranks very high among various countries (Table 2-12). Even though many companies still have an age limit system set at 60 or below, more than $70 \%$ of men aged 60 to 64 are working at a second job after retiring, and $35.6 \%$ of men aged 65 or over are also working. A JILI opinion-survey conducted on workers aged 20 to 59 , revealed that $32.7 \%$ of the respondents wanted to carry on working after retirement, and $31.0 \%$ answered that "if anything, they wanted to work". Thus it can be concluded that those with a willingness to work after retirement exceed $60 \%$ (Figure 2-18). As to the reasons of this willingness, almost $50 \%$ of them referred to the "Coverage of living expenses" (Figure 2-19).

We have mentioned a labor shortage in Japan. This is quite true for young workers, but the ratio of effective labor demand to effective supply concerning older workers is still far below than $100 \%$, showing that most companies still want to employ young people and are not yet fully prepared for the aging of the work force. However, a few companies have introduced measures "to extend age limit and to employ retired people", or "to increase employment of non-new middle-aged and older graduates" in order to cope with the present situation of a labor shortage (Table 2-13). As to the problems expected when the age limit is extended to 60 or 65 , many companies point out the necessity of "Consideration to health and medical care", "review of wage schemes and retirement allowance schemes", "review of jobs and working environment", and "protection against lower working efficiency" (Table 2-14).

Lastly, in connection with the growing importance of the service industries in the economy, employment of part-timers is increasing year by year, and their percentage rose from $8.1 \%$ in 1982 to $10.8 \%$ in 1987 in the case of all industries, and from $17.5 \%$ to $26.7 \%$ respectively in the eating and drinking retail business, which recorded the highest rate in this aspect (Table 2-15).

\section{Japanese characteristics of the four pillars and their main problems}

\subsection{Structural characteristics of the four pillars in Japan}

In a relatively short period after the Second World War, Japan has experienced violent social and economic changes involving aging of the population and growing importance of 
the service industry. The percentage of elderly people aged 65 and over was $4.94 \%$ in 1950 , but due to an extension of the average life span and lowering birth rate, the ratio rapidly rose to $5.72 \%$ in $1960,7.06 \%$ in $1970,9.10 \%$ in 1980 and $11.93 \%$ in 1990 . Now the figure is expected to be $16.27 \%$ in $2000,19.96 \%$ in 2010 and to reach the peak of $23.56 \%$ around the year 2020 .

The average life span of Japanese people has also rapidly increased starting around 50 years immediately after the war. Japan is now the number one longevity country in the world. At present the figure is 75 years for men and around 81 for women. Family composition has also changed, in which the number of families with only one person or an old couple (in both cases aged 65 or more) is rapidly increasing.

On the other hand, changes in industrial and employment structures due to increasing weight of the tertiary industry such as service industry in the economy, as well as a slower pace of economic growth after the oil shock, inevitably forced business circles to reconsider the traditional Japanese practice of guaranteeing lifetime employment based on the seniority-wage system. Thus, the employment situation and working environment have been rapidly changing these days, and such a violent change of social and economic environment is gradually affecting people's sense of economic security and their attitude toward the role of the four pillars.

When looking at the change of the structure of the four pillars in Japan after the war, the third (self-help) and the fourth (employment) pillars necessarily played the central role in the period of reconstruction after the war because neither public pension schemes nor corporate pension plans were adequately prepared at that time. This situation changed in the period of high economic growth, when the first pillar, mainly based on employees' pension schemes, was reinforced. People came to expect much from the first pillar, but emphasis was still on the third and the fourth pillars.

Household savings rates were high, and life insurance policy owners rapidly increased in this period. Many aged workers continued to work after the age limit of 55, or even after they started to receive public pension at the age of 60 . During the 1970's, the period of stable growth and after, Japan entered into an era of an aging society with lower economic growth rate, and financial crisis of the social security system became an urgent problem. $\mathrm{Re}$ examination of the public pension system started, and the roles to be assigned to each of the so-called three pillars came up for discussion, often laying emphasis on the importance of the second pillar (corporate pension) and the third pillar (savings or life insurance).

At the same time, the government implemented policies to encourage self-help efforts of individuals, such as Workers Asset Formation Annuities and the tax-exempt system for individual pension plans. Measures to create favorable environments to employ the aged people were also introduced, which included the Law Concerning the Stabilization of Employment for Older Workers and measures to promote the extension of age limit up to 60. At present, in the period of self-sustained growth and expansion, Japan is groping for the best way to combine the four pillars to cope with the coming peak of aging process in the first quarter of the 21 st century. As the first step for this, reform of the public pension system is in the process of being implemented.

Looking back the trends of the four pillars in Japan after the war, we notice that economic security of people has been actually relied on the third and the fourth pillars, and that the first pillar started to function only after 1970 . The history of the second pillar is even shorter. Full-scale corporate pension plans and the development of the market for 
them started from 1975 on, and they have still many problems; for example, many of the beneficiaries of the plans prefer to get a lump-sum payment instead of pension, and the plans are not yet adopted by many middle and small-sized enterprises, and so on. However, we should not forget that the seniority wage system together with lifetime employment practice have played a very important role in economic security for employees. This system of Japanese-style management has been the basis of the four pillars in Japan.

A concept of the three pillars existed in Japan, but the idea of the four pillars, which includes an aspect of employment, has not been discussed much here. However, the actual situation of economic security for Japanese people has developed along the line of the four pillars in which the fourth pillar has played a very important role since early days. The early retirement system with age limit uniformly at 55 years, which is not usually the case in Western countries, may be a factor to promote re-employment practice of aged workers in Japan. The other side of the Japanese employment system, that is, lifetime employment practice, has contributed to the employees' sense of loyalty and unity with the company. More often than not, working for the company has become the "meaning and value of life" for many "organization (company) men" (an ironic expression referring to the workaholic). This is another factor which prompts once-retired workers to want to work. Actually they want to find the meaning of life in their work. In addition, older people in Japan continue to work often for the reasons of "keeping healthy" and "maintaining social participation". These factors may play a considerable role in keeping Japanese aged workers' participation rate higher than that of Western countries. Considering these factors, the role of the fourth pillar (employment) will remain to be important even from now on. However, we should not overlook fundamental changes in the role of employment among the four pillars.

We should be aware of the transformation of the paradigm concerning the four pillars. Namely, before, the aged people worked, or were forced to work, to secure their living. Now they work more for their health, or work to lead a worthwhile life, and they can flexibly make a choice among permanent, part-time, or temporary jobs. In other words, we have to change our viewpoint towards employment of the aged people. It is no longer a "necessary evil" in a pre-matured society (compelled by age limit at 55 and the incompetence of three pillars as economic security means). Rather, they should work as a result of their free choice in a mature society where the service industry plays a greater role in the economy. Therefore, it is necessary now to revise employment policies for the aged people in such a way that the aged people can make a choice in selecting their job according to their health conditions and working ability, with financial support from the public pension schemes which should be flexible in terms of pension age and of the benefit amount while working.

We have not mentioned a kind of fifth pillar in Japan, that is, support within one's family. It is true that the family system greatly changed after the war from a big family system to a smaller family and finally to a nuclear family with the advancement of the urbanization process. As a result, it is also true that a family's function to support older people has much reduced. Still, if compared to the examples of Western countries, a ratio of families where an older couple lives together with their children is high in Japan. Especially when one of the parents dies, the surviving one is very often taken in by the family of his/her child. The percentage of families composed of three generations in the total households decreased from $19.2 \%$ in 1970 to $15.3 \%$ in 1986 , but the absolute number of such families has not changed much, accounting for 5.76 million households in 1986. The ratio (of three generation families) is particularly high (45\%) in cases where the aged member 
reached 75 years old (for men) or 70 (for women) (Table 3-1). Based on these figures, it is expected that three-generation families will increase with the advancement of the aging process of the population. As a result, it is possible that an aged person will be cared for by a daughter or a daughter-in-law at home when he/she becomes in need of such care. The government is advocating this kind of practice as a Japanese virtuous deed in the social setting mentioned above. However, on the women's side, there is much criticism against such practice especially by dauthers-in-law. They argue that such practice will hinder women's social participation.

\subsection{Tasks to be tackled in relation to the four pillars}

We can point out the following as main tasks to be considered in relation to the four pillars in Japan.

a) Linking of the pension age to the retirement age

Up to around 1974, most Japanese companies adopted a retirement system of age 55, while the pension age was fixed at 60 for the employees' pension schemes. This meant that retired employees had to fill this 5-year gap by working at some other place or by finding other means of income, for instance, using a corporate pension plan as a "stop-gap pension". Therefore the urgent task for companies was to raise retirement age up to 60 . Thus the number of companies which extended their retirement age to this level gradually increased to $63.9 \%$ of the total in 1990 (Figure $2-16$ ). However, the remaining companies, $36.0 \%$ of the total, still fix the age limit below 60 , and the proportion of such companies is much greater for the smaller-sized companies (Table 2-10). The task at the moment is hence to promote adoption of the 60-year retirement system.

As stated before, there is a proposal to gradually (over 20 years) raise the pension age to 65 which is the same level as Western countries. If this proposal is adopted, then the gap between retirement age and the pension age will be further widened and the problem will become more serious. It was because of the concern for this situation where there are still few companies which do adopt 60 -year retirement system, much less companies with 61 or over age limit, that the proposal to raise the pension age to 65 was dropped from the final draft of the government. Therefore another urgent task is to review the 60-year retirement system and to promote continued employment practice up to the age of 65 , through an extension-of-service-year system or a re-employment program, if retiring workers so opt.

Of course individual difference will be widened in terms of physical stamina and healthy conditions if people reach the age 60 or over. Various measures should be implemented so that the aged workers can work comfortably and safely at an improved and rearranged workshop according to their changes in mental and physical conditions with the age, and thus the possibility of.industrial injury can be prevented.

b) Problems of the corporate pension plans

Importance of the second and the third pillars are increasing in the process of reviewing the first pillar (social security system). General adoption of corporate pension plans by companies started in 1975 . At that time $32.9 \%$ of companies had such plans and then the figure increased to $48.1 \%$ in 1985 , and to more than half $(50.7 \%$ ) in 1989 (Table $3-2$ ). Most large-scale corporations (having 1,000 employees or more) implement such plans, but the smaller the size of the company, the lower the proportion of companies having the plans. As for the companies which employ 30-99 workers, only $44 \%$ of them have corporate pension 
plans, about half of the ratio compared to large enterprises, a fact that special promotional policies should be taken for the adoption of pension plans by smaller companies.

The corporate pension plans are mainly composed of the Employees' Pension Fund and Qualified Retirement Pension Plan, but there is a remarkable difference in tax treatment between the two pensions, and it is often pointed out that tax incentives for qualified pensions should be raised to the same level as the employees's fund. There are also many points to be revised or improved including: introduction and improvement of a benefitpayment guarantee system, an increase of benefit level, maintenance of the real value of pensions to be paid, introduction of tax incentives for defined contribution plans, and so on.

Many beneficiaries prefer to be paid a lump sum benefit in the case of the qualified plans because the taxation system treats this payment more favorably than other methods. Even in the case of employees' pension fund (which is a semi-public pension system) only about $60 \%$ of the beneficiaries select benefits to be paid in the form of pension; the remaining $40 \%$ opt for lump sum payment (Table 3-3). This is a problematic phenomenon when considering the original purpose of the pension system as provisions for old age, so the taxation system for recipients of pension should be improved so that they could get equal or even more favorable tax treatment compared to recipients of lump sum retirement.

c) Trends of dropping savings rate - the need for improvement of the taxation system on life insurance and pensions

The household savings rate in Japan is still on a high level if compared to that of Western countries. However, the rate has been dropping from the peak figure of $23.5 \%$ in 1974 , to $14.8 \%$ in 1988 and $13.5 \%$ in 1989 . If this tendency continues, then the figure will be less than $10 \%$ in the 21 st century, coming nearer to the level of the United States. Indeed the rate will not suddenly drop for some time because, in the aging process of society, people will save for the future. Once the aging process reaches its peak, however, the proportion of people already aged who withdraw their savings will exceed those who save for the future days, and the savings rate will drop.

If the government agrees with the self-help efforts of people, it should bring about a policy to encourage such efforts, which could lead to the prevention of the savings rate from dropping. It is especially necessary for the government to grant tax incentives for long-term savings for one's old age, such as private pension insurance, long-term life insurance and so on, which are very vulnerable to inflation. Improvement of the tax system on life insurance and pension plans is still an important task to be settled although a tax-exempt measure has already been implemented for premiums of private pension insurance.

d) Changes in the labor market and re-examination of Japanese style employment practice

Recently we have seen a considerable change in the labor market in Japan. The Japanese economy has been suffering from labor shortage for several years caused by a great increase of labor demand even though there in an abundant labor supply. It is said that mismatching between labor supply and labor demand is expanding, backed by the following situation:

(1) Insufficient measures on the part of enterprises to meet the aging process of the work force,

(2) Labor management by enterprises lacks flexibility to cope with the job seekers' enhanced needs in a social setting of higher educational backgrounds and higher income level as a whole, 
(3) Personal development programs are not geared to the change of the occupational structure in the age of information-oriented society with sophisticated needs of consumers', and

(4) There are differentials of employment opportunities among various regions.

(cf. "To labor shortage" by the Employment Security Bureau, pp. 5-6.)

The number of companies which intend to employ workers aged 60 or over is increasing as is shown by Table 3 -4. However, the general setting of the work place is not yet suitable to accept aged workers. Review of the working environment for the aged workers is thus a pressing problem, also the implementation of a flexible working system, the revision of ability evaluation and wage scheme would be also important in utilizing older workers (Table 3-5).

In addition to the problem of an increase in aged workers, a remarkable participation of women in the labor market, in the form of part-timers in particular, can be seen these days. In a society with increasing graduates from higher educational institutions, more and more girls go to university. It is said that the number of female graduates from university (including two-year colleges) who are newly employed in 1991 exceeded that of male graduates. Women's participation rate in the labor market, not only young female but also those from every age group below the 60 years bracket, has increased since 1975, and the tendency is expected to continue in the future (Figure 3-1). Besides, the younger generation's way of looking at work" is quite different from that of older generations. Young workers attach greater importance to their private lives, hobbies or their leisure" time than working for the company. Their separations rate is rather high (Table 3-6). They dislike to be bound by the company and young workers, who do not become full-time employees but work only on a temporary or part-time basis, are increasing. There are many cases where new employees (university graduates) who start work, soon leave the company and look for another job. On the other hand, it is expected that companies, especially in retail trade, will increasingly rely on part-timers and "free worker" (Table 3-7).

Many elderly people, women, the young, and professional workers want to take a job suitable to his/her liking. These changes in the supply side of labor are further pushed by the structural change in labor demand caused by the growing importance of the service industry in the economy and development of information networks. As a resut, diversification in the structure of employment will be pushed further, including part-time work, temporary help business, flextime work, telecommuting and so on (Figure 3-2).

It may be said that mismatching between demand and supply in the labor market and the problem of labor shortage has been brought about because the enterprises could not cope with the structural change in the labor market. One of the most urgent tasks is to create and improve employment conditions and those of the working environment in order to accept aged workers who are increasing in number and well motivated to work.

The same change in the labor market is also compelling a fundamental readjustment of Japanese style employment practice based on lifetime employment and the seniority-wage system. 
Table 1-1 International comparison in the speed of population aging

\begin{tabular}{|c|c|c|c|}
\hline \multirow[b]{2}{*}{ Country } & \multicolumn{2}{|c|}{ Year in which the aged population ( 65 and over) reaches } & \multirow{2}{*}{$\begin{array}{l}\text { Time required to increase } \\
\text { from } 7 \text { to } 14 \%\end{array}$} \\
\hline & $7 \%$ & $14 \%$ & \\
\hline Japan & 1970 & 1995 & 25 Years \\
\hline U.S.A & 1945 & 2020 & $75 \prime \prime$ \\
\hline U.K. & 1930 & 1975 & 45 \\
\hline Western Germany & 1930 & 1975 & 45 \\
\hline France & 1865 & 1995 & $130 \prime \prime$ \\
\hline Sweden & 1890 & 1975 & 85 \\
\hline
\end{tabular}

Source : Institute of Population Problems. Ministry of Health and Welfare (1986)

Table 1-2 Trend of aged population and its projection

\begin{tabular}{|c|c|c|c|c|c|c|c|}
\hline Year & $\begin{array}{c}\text { Total } \\
\text { population }\end{array}$ & $\begin{array}{l}\text { Population aged } \\
65 \text { and over } \\
\text { (A) }\end{array}$ & $\begin{array}{l}\text { Its percent } \\
\text { in total } \\
\text { population }\end{array}$ & $\begin{array}{l}\text { Population } \\
\text { aged } 75 \\
\text { and over }\end{array}$ & $\begin{array}{l}\text { Its percent } \\
\text { in total } \\
\text { population }\end{array}$ & $\begin{array}{l}\text { Population aged } \\
\text { from } 15 \text { to } 64 \\
\text { (B) }\end{array}$ & (A) /(B) \\
\hline 1920 & 10 thousand & $\begin{array}{l}10 \text { thoussand } \\
294\end{array}$ & $53^{*}$ & 10 thousand & $13_{3}^{x}$ & 10 thousand & $9^{x}$ \\
\hline 1950 & 8,412 & $\begin{array}{l}204 \\
416\end{array}$ & 4.9 & 107 & 13 & $\begin{array}{l}5,201 \\
5.017\end{array}$ & 8.3 \\
\hline 1960 & 9,430 & 540 & 5.7 & 164 & 1.7 & 6.047 & 8.9 \\
\hline 1970 & 10,467 & 739 & 7.1 & 224 & 2.1 & 7.212 & 10.3 \\
\hline 1980 & 11,706 & 1.065 & 9.1 & 366 & 3.1 & 7,883 & 13.5 \\
\hline 1985 & 12,105 & 1,247 & 10.3 & 471 & 3.9 & 8.251 & 15.1 \\
\hline 1986 & 12,167 & 1.287 & 10.6 & 495 & 4.1 & 8.337 & 15.4 \\
\hline 1987 & 12,226 & 1,332 & 10.9 & 523 & 4.3 & $8,419^{\circ}$ & 15.8 \\
\hline 1990 & 12,423 & 1,482 & 11.9 & 592 & 4.8 & 8.627 & 17.2 \\
\hline 1995 & 12,757 & 1,801 & 14.1 & 699 & 5.5 & 8.717 & 20.7 \\
\hline 2000 & 13,119 & 2,134 & 16.3 & 845 & 6.4 & 8,626 & 24.7 \\
\hline 2005 & 13,425 & 2.420 & 18.0 & 1,047 & 7.8 & 8,489 & 28.5 \\
\hline 2010 & 13,582 & 2.710 & 20.0 & 1.246 & 9.2 & 8,342 & 32.5 \\
\hline 2015 & 13.594 & 3,064 & 22.5 & 1,389 & 10.2 & 8,142 & 37.6 \\
\hline 2020 & 13.530 & 3.188 & 23.56 & 1,531 & 11.3 & 8,110 & 39.3 \\
\hline 2021 & 13,516 & 3,187 & 23.58 & 1,524 & 11.3 & 8,110 & 39.3 \\
\hline 2025 & 13,464 & 3.147 & 23.4 & 1.737 & 12.9 & 8,110 & 38.8 \\
\hline
\end{tabular}

Note : $(A) /(B)$ means dependency ratio of agéd population.

Source : Population Census (1920-85) and population projection (1986-87) by Management and Coordination Agency. Institute of Population Problems. Ministry of Health and Welfare (1990- ).

Table 1-3 Projection of population aging (selected countries, percent of aged population 65 and over)

\begin{tabular}{|c|c|c|c|c|c|c|}
\hline & Japan & U.S.A. & U.K. & $\begin{array}{c}\text { Western } \\
\text { Germany }\end{array}$ & France & Sweden \\
\hline $\begin{array}{c}\text { (actual) } \\
1984 \\
1985\end{array}$ & 10.3 & 12.0 & 14.8 & 14.6 & & 17.1 \\
\hline 1990 & 11.9 & 12.2 & 15.6 & 15.1 & 13.0 & 17.7 \\
\hline 2000 & 16.3 & 12.0 & 15.3 & 16.7 & 14.7 & 17.2 \\
\hline 2020 & 23.6 & 15.4 & 17.8 & 21.2 & 18.0 & 21.8 \\
\hline 2025 & 23.4 & 17.2 & 18.7 & 22.5 & 19.3 & 22.2 \\
\hline
\end{tabular}

Source : Population Census by Management and Coordination Agency. Institute of Population Problems. Ministry of Health and Welfare. Demographic Yearbook by U.N. . Current Population Reports by Council of Europe 
Table 1-4 Ratio of households with member of 65 and over

(\%)

\begin{tabular}{|c|c|c|c|c|c|c|c|c|}
\hline & \multirow[b]{2}{*}{ Total } & \multirow[b]{2}{*}{$\begin{array}{l}\text { One-person } \\
\text { household }\end{array}$} & \multicolumn{3}{|c|}{ A married couple only } & \multirow{2}{*}{$\begin{array}{l}\text { A married } \\
\text { couple with } \\
\text { unmarried } \\
\text { child (ren) }\end{array}$} & \multirow[b]{2}{*}{$\begin{array}{l}\text { A couple } \\
\text { with } \\
\text { parent (s) }\end{array}$} & \multirow[b]{2}{*}{ Others } \\
\hline & & & Total & $\begin{array}{l}\text { One of the } \\
\text { couple is } \\
\text { below } 65 \\
\end{array}$ & $\begin{array}{l}\text { Both of the } \\
\text { couple are } \\
65 \text { and over }\end{array}$ & & & \\
\hline 1975 & 100.0 & 8.6 & 13.1 & $\ldots$ & & 9.6 & 54.4 & 14.4 \\
\hline 1980 & 100.0 & 10.7 & 16.2 & 7.7 & 8.5 & 10.5 & 50.1 & 12.5 \\
\hline 1982 & 100.0 & 10.8 & 17.1 & 8.0 & 9.1 & 10.1 & 48.9 & 13.0 \\
\hline 1983 & 100.0 & 11.6 & 17.7 & 8.3 & 9.5 & 10.6 & 47.4 & 12.7 \\
\hline 1984 & 100.0 & 12.5 & 18.3 & 8.6 & 9.7 & 10.9 & 46.0 & 12.2 \\
\hline 1985 & 100.0 & 12.0 & 19.1 & 8.5 & 10.6 & 10.8 & 45.9 & 12.2 \\
\hline 1986 & 100.0 & 13.1 & 18.2 & 8.0 & 10.3 & 11.1 & 44.8 & 12.7 \\
\hline 1987 & 100.0 & 13.0 & 19.0 & 7.5 & 11.5 & 10.9 & 43.9 & 13.2 \\
\hline 1988 & 100.0 & 13.7 & 20.0 & 8.2 & 11.9 & 11.5 & 41.7 & 13.1 \\
\hline
\end{tabular}

Source: Ministry of Health and Welfare

Table 1-5 Trends of total fertility rate in selected countries

\begin{tabular}{|l|c|c|c|c|c|c|c|c|c|}
\hline & 1965 & 1970 & 1975 & 1980 & 1985 & 1986 & 1987 & 1988 & 1989 \\
\hline Japan & 2.14 & 2.13 & 1.91 & 1.75 & 1.76 & 1.72 & 1.69 & 1.66 & 1.57 \\
U.S.A. & 2.93 & 2.48 & 1.77 & 1.84 & 1.84 & 1.84 & 1.87 & 1.93 & - \\
Sweden & 2.42 & 1.94 & 1.78 & 1.68 & 1.73 & 1.79 & 1.84 & 1.96 & 2.02 \\
U.K. & 2.85 & 2.45 & 1.81 & 1.89 & 1.80 & 1.78 & 1.81 & 1.84 & 1.85 \\
France & 2.84 & 2.47 & 1.93 & 1.95 & 1.82 & 1.84 & 1.82 & 1.82 & 1.81 \\
Western Germany & 2.50 & 2.02 & 1.45 & 1.45 & 1.28 & 1.35 & 1.38 & 1.42 & 1.39 \\
Italy & 2.55 & 2.46 & 2.19 & 1.66 & 1.41 & 1.33 & 1.28 & 1.33 & 1.29 \\
\hline
\end{tabular}

Source: United Nations Demographic Yearbook, Council of Europe, Recent Demographic Developments in the Member States of Council of Europe 1989 and each country's authorized statistics

Table 1-6 Trends of unmarried rate by age

(\%)

\begin{tabular}{|l|r|r|r|r|}
\hline \multicolumn{1}{|c|}{ Age } & 1965 & 1975 & 1985 & 1989 \\
\hline Male & & & & \\
$20 \sim 24$ & 90.3 & 88.0 & 92.1 & - \\
$25 \sim 29$ & 45.7 & 48.3 & 60.4 & - \\
$30 \sim 34$ & 11.1 & 14.3 & 28.1 & - \\
$35 \sim 39$ & 4.2 & 6.1 & 14.2 & - \\
$40 \sim 44$ & 2.4 & 3.7 & 7.4 & - \\
$45 \sim 49$ & 1.7 & 2.5 & 4.7 & - \\
Female & & & & \\
$20 \sim 24$ & 68.1 & 69.2 & 81.4 & 85.7 \\
$25 \sim 29$ & 19.0 & 20.9 & 30.6 & 37.3 \\
$30 \sim 34$ & 9.0 & 7.7 & 10.4 & 12.0 \\
$35 \sim 39$ & 6.8 & 5.3 & 6.6 & 6.7 \\
$40 \sim 44$ & 4.7 & 5.0 & 4.9 & 5.0 \\
$45 \sim 49$ & 3.0 & 4.9 & 4.3 & 3.5 \\
\hline
\end{tabular}

Source : Estimation based on data by Management and Coordination Agency 
Table 1.7 Trends of contribution rate of Employees' Pension Insurance

(permillage)

\begin{tabular}{|c|c|c|c|c|}
\hline & \multicolumn{4}{|c|}{ contribution rate } \\
\hline & I class region & 2 class region & 3 class region & 4 class region \\
\hline 1942. $6 \sim 1944.9$ & 64 & 64 & 80 & - \\
\hline $1944.10 \sim 1947.8$ & 110 & 110 & 150 & - \\
\hline 1947. 9 1948. 7 & 94 & 68 & 126 & - \\
\hline 1948. 8 1954. 4 & & & & \\
\hline Constant & 94 & 55 & 123 & 78 \\
\hline Tentative & 30 & 30 & 35 & 26 \\
\hline 1954. $5 \sim 1960.4$ & 30 & 30 & 35 & 30 \\
\hline 1960. 5 1965. 4 & 35 & 30 & 42 & 35 \\
\hline 1965. $5 \sim 1969.10$ & $55(31)$ & (19) & $67(31)$ & 55 \\
\hline $1969.11 \sim 1971.10$ & $62(36)$ & ( 24$)$ & $74(36)$ & 62 \\
\hline $1971.11 \sim 1973.10$ & $64(38)$ & (26) & $76(38)$ & 64 \\
\hline $1973.11 \sim 1974.10$ & $76(50)$ & $(36)$ & $88(50)$ & 76 \\
\hline $1974.11 \sim 1976.7$ & $76(48)$ & ( 34$)$ & $88(48)$ & 76 \\
\hline 1976. 8 1980. 9 & $91(61)$ & (47) & $103(61)$ & 91 \\
\hline $1980.10 \sim 1985.9$ & $106(74)$ & $(60)$ & $118(74)$ & 106 \\
\hline $1985.10 \sim 1989.12$ & $124(92)$ & ( 83$)$ & $136(104)$ & 124 \\
\hline 1990. $1 \sim 1990.12$ & $143(111)$ & $(108)$ & $161(129)$ & 143 \\
\hline 1991. 1 & $145(113)$ & $141.5(111.5)$ & $163(131)$ & 145 \\
\hline
\end{tabular}

Note: Figures in brackets show the rate for specially treated person.

1 class region: male, 2 class region: female, 3 class region: miner/seaman,

4 class region: specially admitted.

Source: Health and Welfare Statistics Association.

Table 2-1 Public pension schemes in selected countries

\begin{tabular}{|c|c|c|c|c|c|}
\hline County & Germany & Sweden & United Kingdom & U.S.A & Japan \\
\hline Kind of Scherne & Laborer/Worker Pension & National Pension & National Insurance & $\begin{array}{l}\text { Old-age, survivors and dis- } \\
\text { ability lnsurance }\end{array}$ & $\begin{array}{l}\text { Emplyees Pension Insur- } \\
\text { ance }\end{array}$ \\
\hline Coverage & $\begin{array}{l}\text { Laborer (Blue Color) } \\
\text { Worker (While Color) } \\
\end{array}$ & people & people & $\begin{array}{l}\text { General emplovee } \\
\text { self-employed etc. }\end{array}$ & General employee \\
\hline $\begin{array}{l}\text { Start of pension pay- } \\
\text { ment ( } F \text {. 1990) }\end{array}$ & 65 & 65 & Male 65. Female 60 & 65 & $\begin{array}{l}\text { Male } 60 \text {, fernale } 56 \\
\text { Pulled up to } 60 \text { annually till } \\
2000\end{array}$ \\
\hline $\begin{array}{l}\text { Monthiy amount of old } \\
\text { age pension }(A)\end{array}$ & $\begin{array}{l}1989.7 \\
\text { Total average monthly pen- } \\
\text { sion } \\
¥ 82,178 \text { (DM1, 119.9) } \\
\text { Laborer Pension } \\
¥ 70.173 \text { (DM 956.3) } \\
\text { Worker Pension } \\
¥ 100.809 \text { (DM } 1.373 .8)\end{array}$ & $\begin{array}{l}1989.1 \\
\text { Basic pension } \\
\text { single } ¥ 47.765 \\
\quad(C r 2,232.0) \\
\text { couple } ¥ 78.116 \\
(C r 3.650 .3) \\
1988.12 \\
\text { Average additional pensions } \\
\quad 69.216(C r 3.310 .2)\end{array}$ & 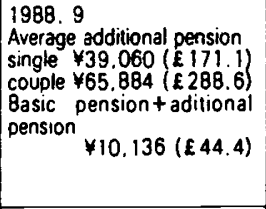 & $\begin{array}{l}\text { 1989. } 3 \\
\text { Total average pension } \\
\text { single } ¥ 74.305 \\
(\$ 538.6) \\
\text { couple } ¥ 112.658 \\
(\$ 816.6)\end{array}$ & $\begin{array}{l}1990.3 \\
\text { Iotal average pension } \\
\\
\quad ¥ 137.978\end{array}$ \\
\hline $\begin{array}{l}\text { Average monthly wages } \\
\text { (Manufacluring. 1988) } \\
\text { (8) }\end{array}$ & $\begin{array}{l}\begin{array}{l}¥ 232,477 \\
(\mathrm{DM} 3,185.9)\end{array}\end{array}$ & $\begin{array}{l}¥ 252.596 \\
(\mathrm{Cr} 12.080 .1)\end{array}$ & $\begin{array}{l}¥ 183.737 \\
(E 775.1 / 1987)\end{array}$ & $\begin{array}{l}¥ 232,982 \\
(\$ 1,818.0)\end{array}$ & $\begin{array}{l}¥ 336,648 \\
(1989)\end{array}$ \\
\hline$A / B$ & $35.2 \%$ & $\begin{array}{l}57.6 \% \text { (basic pensiont } \\
\text { additional pension) }\end{array}$ & $\begin{array}{l}\text { 43. } 0 \% \text { (basic pensiont } \\
\text { additional pension) }\end{array}$ & $44.9 \%$ & $41.0 \%$ \\
\hline $\begin{array}{l}\text { Contribution Rate } \\
(1990)\end{array}$ & $\begin{array}{l}187.0 / 1.000 \\
\text { (50\% by employee. } 50 \% \text { by } \\
\text { employer) }\end{array}$ & $\begin{array}{l}\text { 8asic pension } 74.5 / 1.000 \\
\text { Additional pension } \\
130.0 / 1.000 \\
\text { (Paid by employer. sell-em- } \\
\text { ployed by himself) }\end{array}$ & $\begin{array}{l}20 / 1.000 \sim 90 / 1.000 \\
(8 e n i f i c i a n) \\
50 / 1,000 \sim 104.5 / 1.000 \\
\text { (Employer) } \\
\text { (Progressive contribution) }\end{array}$ & $\begin{array}{l}124.0 / 1,000 \\
\text { (50\% by employee, } 50 \% \text { by } \\
\text { employer) }\end{array}$ & $\begin{array}{l}\text { Male } 143.0 / 1.000 \text { (Stan- } \\
\text { dard income base) } \\
\text { ( } 50 \% \text { by employee. } 50 \% \text { by } \\
\text { employer) } \\
\text { (110/1.000 on lotal in- } \\
\text { come base) }\end{array}$ \\
\hline National Subsidy & $\begin{array}{l}\text { To bear the shortage } \\
(17 \% \text { of tolal pension in } \\
1989)\end{array}$ & $\begin{array}{l}\text { To bear the shortage } \\
\text { (15\% of lotal pension in } \\
1988)\end{array}$ & $\begin{array}{l}\text { None } \\
\text { (1989) }\end{array}$ & None & $\begin{array}{l}1 / 3 \text { of basic pension pay- } \\
\text { ment }\end{array}$ \\
\hline
\end{tabular}

Source: "Yearbook of Labour Statistics" by ILO, "International Financial Statistics" by IMF. 
Table 2-2 Public pension schemes in Japan (March 1990)

\begin{tabular}{|c|c|c|c|c|c|c|c|c|}
\hline Pension Schemes & Insured & Insurer & $\begin{array}{c}\begin{array}{c}\text { Number of } \\
\text { insured } \\
\text { (10 Thousand) } \\
\text { (1) }\end{array} \\
\end{array}$ & $\begin{array}{c}\text { Eligible persons } \\
\text { for old age pen- } \\
\text { sion (10 thousand) } \\
\text { (2) }\end{array}$ & $\begin{array}{c}\text { Mature Level } \\
\text { (2) } \\
\text { (1) }\end{array}$ & $\begin{array}{l}\text { Average monthiy } \\
\text { amount of old } \\
\text { age (retired) } \\
\text { pension } \\
\text { p pothousand }\end{array}$ & Contribution & Pensionable age \\
\hline \multirow[t]{4}{*}{$\begin{array}{l}\text { National pension } \\
\text { (Basic pension) }\end{array}$} & $\begin{array}{l}\text { Class } 1 \text { insured } \\
\text { (Self-employed) }\end{array}$ & \multirow{3}{*}{ Government } & 1.816 & \multirow{2}{*}{758} & \multirow{3}{*}{-} & \multirow{2}{*}{3.1} & \multirow[t]{3}{*}{$\begin{array}{c}\text { (Since April 1991) } \\
\text { Beneficiary } \\
¥ 9.000\end{array}$} & \multirow{3}{*}{65} \\
\hline & $\begin{array}{l}\text { Class } 3 \text { insured } \\
\text { Wives of sal. people) }\end{array}$ & & 1.179 & & & & & \\
\hline & $\begin{array}{l}\text { Class } 2 \text { insured } \\
\text { (Salaried pepole) }\end{array}$ & & 3.573 & 393 & & - & & \\
\hline & Total & - & 6.568 & 1.151 & $17.5 \%$ & - & - & - \\
\hline $\begin{array}{l}\text { Einployees pension } \\
\text { insurance }\end{array}$ & $\begin{array}{l}\text { Salaried people in pri- } \\
\text { vate sector }\end{array}$ & Government & 2.992 & 451 & 15.1 & 138 & $\begin{array}{l}\text { Male } 14.5 \% \\
\text { Female } 14.15 \\
\text { Coal miner } \\
\text { Seamen }\end{array}$ & $\begin{array}{l}\text { Male } 60 \\
\text { Female } 57 \\
(1999 \sim 60) \\
\text { Coal miner } \\
\text { Seamaen }\end{array}$ \\
\hline $\begin{array}{l}\text { National public ser. } \\
\text { vice etc. M.A.A. }\end{array}$ & & & & & & & & \multirow{8}{*}{$\begin{array}{l}58 \\
(60 \text { in 1995) } \\
\text { Self-defense oHl. } \\
\text { clai } 55 \\
(60 \text { in 1995) }\end{array}$} \\
\hline Feder ation & $\begin{array}{l}\text { National governinent } \\
\text { servarit }\end{array}$ & $\begin{array}{l}\text { Federation of national } \\
\text { public service efc. M. } \\
\text { A.A. }\end{array}$ & 114 & 48 & 42.0 & 18.5 & 152 & \\
\hline Japan raltway & $\begin{array}{l}\text { Employees ol railway } \\
\text { indusiny etc. }\end{array}$ & $\begin{array}{l}\text { Japan raliway M.A. } \\
\text { A. }\end{array}$ & 20 & 34 & 167.4 & 17.5 & 19.09 & \\
\hline $\begin{array}{l}\text { Nippon telephone } \\
\text { and telegram }\end{array}$ & $\begin{array}{l}\text { Employees of Nippon } \\
\text { lelephone and lelegram }\end{array}$ & $\begin{array}{l}\text { Nippon relephone } \\
\text { and telegram M.A.A. }\end{array}$ & 28 & 11 & 37.3 & 19.0 & 14.02 & \\
\hline $\begin{array}{l}\text { Japan tobacco } \\
\text { industiy }\end{array}$ & $\begin{array}{l}\text { Employees of Japan } \\
\text { lobacco industry }\end{array}$ & $\begin{array}{l}\text { Japan robaco MA. } \\
\text {. }\end{array}$ & 3 & 2 & 94.2 & 17.0 & 17.07 & \\
\hline $\begin{array}{l}\text { Local public service } \\
\text { M.A.A. }\end{array}$ & $\begin{array}{l}\text { Local government } \\
\text { servant }\end{array}$ & $\begin{array}{l}\text { Local public service } \\
\text { M.A.A. }\end{array}$ & 328 & 100 & 30.6 & 20.1 & 14.16 & \\
\hline $\begin{array}{l}\text { Privale school } \\
\text { leachers' \& } \\
\text { employees M.A.A. }\end{array}$ & $\begin{array}{l}\text { Teachers and } \\
\text { employees ol private } \\
\text { schools }\end{array}$ & $\begin{array}{l}\text { Private school } \\
\text { leachers' \& } \\
\text { employees M.A.A. }\end{array}$ & 38 & 2 & 6.1 & 16.6 & 11.8 & \\
\hline $\begin{array}{l}\text { Agricuilural. forestry } \\
\text { \& tishery institutions } \\
\text { employees' M.A A. }\end{array}$ & $\begin{array}{l}\text { Employees of agricul- } \\
\text { lural federation eic. }\end{array}$ & $\begin{array}{l}\text { Agricultural. forestry } \\
\& \text { fishery insitutions } \\
\text { employees M.A.A. }\end{array}$ & 50 & 11 & 21.9 & 14.2 & 16.3 & \\
\hline Total & - & - & 3.573 & 660 & 18.5 & - & - & \\
\hline
\end{tabular}

Table 2-3 Improvement of old age pension payments in occupation

(Before revision)

\begin{tabular}{|r|c|}
\hline Standard monthly pay & Rate of payment \\
\hline$\sim \$ 92,000$ & $80 \%$ \\
$98.000 \sim 150,000$ & 50 \\
$160,000 \sim 200,000$ & 20 \\
\hline
\end{tabular}

(Started in December 1989)

(After revision)

$\square \quad$\begin{tabular}{|r|c|}
\hline Standard monthly pay & Rate of payment \\
\hline$\sim 792.000$ & $80 \%$ \\
$98,000 \sim 110.000$ & 70 \\
$118.000 \sim 134.000$ & 60 \\
$142,000 \sim 160.000$ & 50 \\
$170,000 \sim 180.000$ & 40 \\
$190,000 \sim 200.000$ & 30 \\
$220,000 \sim 240.000$ & 20 \\
\hline
\end{tabular}

Table 2-4 Reasons for adoption of corporate pension

\begin{tabular}{|c|c|c|c|c|c|c|c|c|c|c|c|}
\hline Size & Total & Tax incentive & $\begin{array}{l}\text { Total amount } \\
\text { is more than } \\
\text { lump sum } \\
\text { lamount }\end{array}$ & $\begin{array}{l}\text { External fund- } \\
\text { ing gives } \\
\text { emplorees a } \\
\text { sense of salely }\end{array}$ & $\begin{array}{l}\text { Allowance } \\
\text { cost for } \\
\text { relirement is } \\
\text { levellied }\end{array}$ & $\begin{array}{l}\text { Requirement } \\
\text { by eniployees } \\
\text { or labor } \\
\text { union } \\
\end{array}$ & $\begin{array}{l}\text { Legal require } \\
\text { ment lo keep } \\
\text { retirement } \\
\text { allowance }\end{array}$ & $\begin{array}{l}\text { Only lump } \\
\text { sum parment } \\
\text { is insufficient }\end{array}$ & $\begin{array}{l}\text { More reaso. } \\
\text { nable and } \\
\text { merlt than } \\
\text { others } \\
\end{array}$ & $\begin{array}{l}\text { Contribution } \\
\text { of subslitute } \\
\text { pan is lower }\end{array}$ & Others \\
\hline $\begin{array}{l}\text { Qualified retirement } \\
\text { pension }\end{array}$ & & $\mathbf{x}$ & $x$ & $x$ & $x$ & $x$ & $x$ & $\mathbf{x}$ & $x$ & $\mathbf{x}$ & $*$ \\
\hline$\%$ in lotal & 100.0 & 77.8 & 16.4 & 57.3 & 75.1 & 6.9 & 20.4 & 8.7 & 6.8 & - & 1.1 \\
\hline $\begin{array}{l}3.000 \sim \\
1.000 \sim 2.999 \\
300 \sim 999 \\
\sim \quad 299\end{array}$ & $\begin{array}{l}100.0 \\
100.0 \\
100.0 \\
100.0\end{array}$ & $\begin{array}{l}84.0 \\
80.7 \\
78.3 \\
69.0 \\
\end{array}$ & $\begin{array}{r}29.0 \\
23.5 \\
11.1 \\
7.8 \\
\end{array}$ & $\begin{array}{l}54.0 \\
554 \\
60.6 \\
56.3 \\
\end{array}$ & $\begin{array}{l}88.0 \\
84.9 \\
71.2 \\
60.6 \\
\end{array}$ & $\begin{array}{r}13.0 \\
6.6 \\
5.3 \\
5.6 \\
\end{array}$ & $\begin{array}{l}21.0 \\
19.3 \\
22.1 \\
18.3 \\
\end{array}$ & $\begin{array}{r}2.0 \\
5.4 \\
9.3 \\
16.2 \\
\end{array}$ & $\begin{array}{l}2.0 \\
9.6 \\
8.0 \\
4.9 \\
\end{array}$ & $\begin{array}{l}- \\
- \\
-\end{array}$ & $\begin{array}{l}1.0 \\
0.6 \\
0.9 \\
2.1\end{array}$ \\
\hline $\begin{array}{l}\text { Adjusted pension } \\
\% \text { in lotal }\end{array}$ & 100.0 & 70.1 & 44.5 & 49.2 & 50.8 & 16.6 & 7.6 & 13.6 & - & 8.3 & 7.6 \\
\hline $\begin{array}{l}5.000 \sim \\
3.000 \sim 4.999 \\
\sim 2.999\end{array}$ & $\begin{array}{l}100.0 \\
100.0 \\
100.0\end{array}$ & $\begin{array}{l}73.8 \\
702 \\
68.0\end{array}$ & $\begin{array}{l}47.5 \\
42.1 \\
43.3\end{array}$ & $\begin{array}{l}47.5 \\
52.6 \\
50.0\end{array}$ & $\begin{array}{l}48.8 \\
47.4 \\
51.3\end{array}$ & $\begin{array}{l}15.0 \\
15.8 \\
17.3\end{array}$ & $\begin{array}{l}7.5 \\
5.3 \\
8.0\end{array}$ & $\begin{array}{r}7.5 \\
12.3 \\
18.0\end{array}$ & $\begin{array}{l}- \\
-\end{array}$ & $\begin{array}{l}8.8 \\
1.8 \\
1.0\end{array}$ & $\begin{array}{l}10 \\
35 \\
8.7\end{array}$ \\
\hline
\end{tabular}

Source : Mitsubishi Research Insitute, 198500 Note : Conipanies on ine Tokyo Slock Market, qualified retirement pensoin 634, adjusted pension 301 
Table 2-5 Problems of 'employees' pension fund

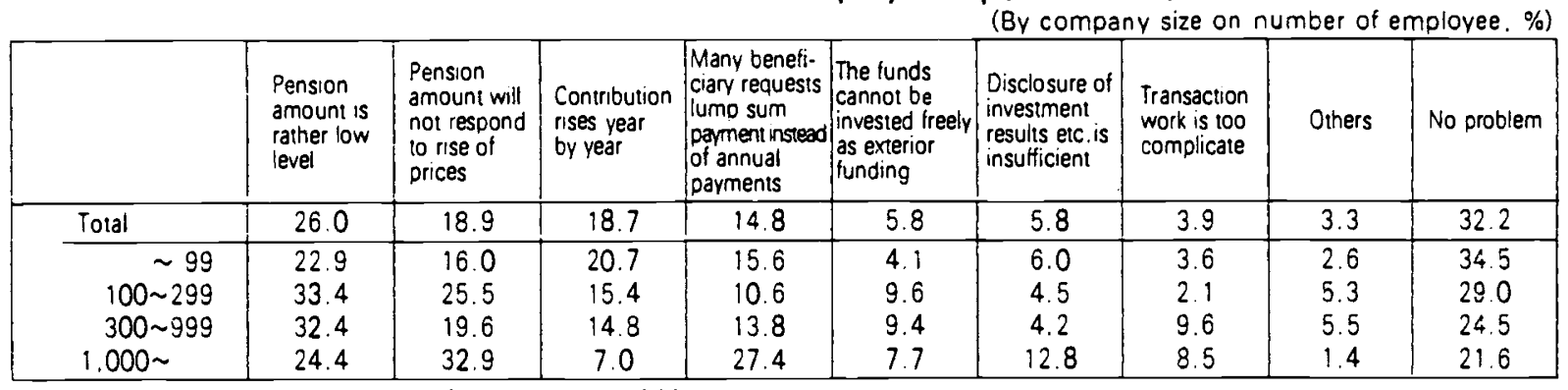

Source : Survey on employees' benefit plan by JILI 1989

Table 2-6 Problems of qualified retirement pension plan

\begin{tabular}{|c|c|c|c|c|c|c|c|c|c|c|}
\hline & $\begin{array}{l}\text { More benefi: } \\
\text { ciary requests } \\
\text { lump sum } \\
\text { payment instead } \\
\text { of annual } \\
\text { payments }\end{array}$ & $\begin{array}{l}\text { Pension } \\
\text { amount } \\
\text { is rather } \\
\text { low level }\end{array}$ & $\begin{array}{l}\text { Pension } \\
\text { amount } \\
\text { will not } \\
\text { respond to nse } \\
\text { of prices }\end{array}$ & $\begin{array}{l}\text { Pension will } \\
\text { not paid for } \\
\text { life }\end{array}$ & $\begin{array}{l}\text { The } \\
\text { eligibility } \\
\text { is disappear } \\
\text { di change of } \\
\text { occupation }\end{array}$ & $\begin{array}{l}\text { Contribution } \\
\text { rises year } \\
\text { by year }\end{array}$ & $\begin{array}{l}\text { The funds } \\
\text { cannot be } \\
\text { invested freely } \\
\text { as exterior } \\
\text { funding }\end{array}$ & $\begin{array}{l}\text { Disclosure of } \\
\text { investment } \\
\text { results etc. is } \\
\text { insufficient }\end{array}$ & $\begin{array}{l}\text { Transaction } \\
\text { work is too } \\
\text { complicate }\end{array}$ & No problem \\
\hline $\begin{array}{l}\text { Number of } \\
\text { empioyee } \\
\text { Total } \\
\end{array}$ & 48.8 & 36.2 & 34.0 & 23.5 & 14.9 & 12.1 & 9.5 & 5.5 & 4.1 & 9.8 \\
\hline $\begin{array}{r}\sim 99 \\
100 \sim 299 \\
300 \sim 999 \\
1.000 \sim\end{array}$ & $\begin{array}{l}47.3 \\
47.0 \\
60.5 \\
51.4\end{array}$ & $\begin{array}{l}38.2 \\
34.2 \\
34.8 \\
23.7\end{array}$ & $\begin{array}{l}34.7 \\
33.0 \\
35.7 \\
22.6\end{array}$ & $\begin{array}{l}20.7 \\
23.6 \\
35.3 \\
30.7\end{array}$ & $\begin{array}{l}16.5 \\
12.4 \\
13.9 \\
17.0\end{array}$ & $\begin{array}{r}13.0 \\
9.9 \\
15.3 \\
5.7\end{array}$ & $\begin{array}{r}5.9 \\
14.0 \\
15.4 \\
8.9\end{array}$ & $\begin{array}{l}5.4 \\
4.2 \\
8.4 \\
9.9\end{array}$ & $\begin{array}{l}5.2 \\
0.9 \\
6.7 \\
6.1\end{array}$ & $\begin{array}{r}11.7 \\
7.8 \\
6.3 \\
7.1\end{array}$ \\
\hline
\end{tabular}

Source : Survey on employees benefit plan by JiLl 1989

Table 2-7 Trend of purposes of savings

\begin{tabular}{|c|c|c|c|c|c|c|c|c|c|}
\hline & $\begin{array}{l}\begin{array}{l}\text { Protection } \\
\text { against illness } \\
\text { and accident }\end{array} \\
\text { and }\end{array}$ & \begin{tabular}{|l|} 
Educational \\
expenditure \\
for child (ren)
\end{tabular} & $\begin{array}{l}\text { Funds for } \\
\text { marriage of } \\
\text { child (ren) }\end{array}$ & \begin{tabular}{|l|} 
Living \\
expenses for \\
old age
\end{tabular} & $\begin{array}{l}\text { Funds for } \\
\text { own land } \\
\text { and house }\end{array}$ & \begin{tabular}{|l|} 
Funds for \\
durable con- \\
sumer goods
\end{tabular} & $\begin{array}{l}\text { Funds for } \\
\text { leisure }\end{array}$ & $\begin{array}{l}\text { Funds for } \\
\text { taxes }\end{array}$ & \begin{tabular}{|l|} 
No special \\
purpose but \\
sense of retief
\end{tabular} \\
\hline Peak & \begin{tabular}{|c|}
$\langle 1975\rangle$ \\
83.2 \\
$(42.2)$ \\
\end{tabular} & \multicolumn{2}{|c|}{\begin{tabular}{|c|}
$\langle 1988\rangle$ \\
64.4 \\
$(18.5)$ \\
\end{tabular}} & \begin{tabular}{|c|}
$\langle 1989\rangle$ \\
51.5 \\
$(23.7)$ \\
\end{tabular} & $\begin{array}{c}\langle 1968\rangle \\
36.6 \\
(-)\end{array}$ & \begin{tabular}{|c|}
$1970\rangle$ \\
13.4 \\
$(2.7)$ \\
\end{tabular} & $\begin{array}{l}\langle 1981\rangle \\
11.4 \\
(1.1)\end{array}$ & $\begin{array}{c}\langle 1963\rangle \\
6.2 \\
(-)\end{array}$ & \begin{tabular}{|c|}
$\langle 1971\rangle$ \\
31.3 \\
$(10.3)$ \\
\end{tabular} \\
\hline 1979 & $\begin{array}{r}76.6 \\
(34.4)\end{array}$ & \multicolumn{2}{|c|}{$\begin{array}{c}53.0 \\
(18.1)\end{array}$} & $\begin{array}{c}39.8 \\
(13.9)\end{array}$ & $\begin{array}{c}33.9 \\
(13.9)\end{array}$ & $\begin{array}{l}8.2 \\
(0.9)\end{array}$ & $\begin{array}{l}9.9 \\
(0.8)\end{array}$ & $\begin{array}{l}3.8 \\
(0.7)\end{array}$ & $\begin{array}{l}27.2 \\
(6.4)\end{array}$ \\
\hline 1980 & $\begin{array}{r}79.1 \\
(36.1) \\
\end{array}$ & \multicolumn{2}{|c|}{$\begin{array}{l}53.5 \\
(18.3)\end{array}$} & $\begin{array}{l}38.4 \\
(11.3)\end{array}$ & $\begin{array}{r}32.0 \\
(15.4)\end{array}$ & $\begin{array}{l}7.8 \\
(0.9)\end{array}$ & $\begin{array}{l}10.0 \\
(0.8)\end{array}$ & $\begin{array}{l}4.8 \\
(0.8)\end{array}$ & $\begin{array}{r}27.2 \\
(5.9)\end{array}$ \\
\hline 1981 & $\begin{array}{r}76.9 \\
(39.0) \\
\end{array}$ & \multicolumn{2}{|c|}{$\begin{array}{l}50.9 \\
(17.9)\end{array}$} & $\begin{array}{r}36.4 \\
(13.4)\end{array}$ & $\begin{array}{c}31.4 \\
(16.2)\end{array}$ & $\begin{array}{l}8.7 \\
(1.4)\end{array}$ & $\begin{array}{l}11.4 \\
(1.1)\end{array}$ & $\begin{array}{l}4.1 \\
(0.8)\end{array}$ & $\begin{array}{r}26.5 \\
(7.6)\end{array}$ \\
\hline 1982 & $\begin{array}{r}78.5 \\
(38.7) \\
\end{array}$ & \multicolumn{2}{|c|}{$\begin{array}{l}52.7 \\
(19.5)\end{array}$} & $\begin{array}{l}42.1 \\
(15.3) \\
\end{array}$ & $\begin{array}{r}27.1 \\
(13.2) \\
\end{array}$ & $\begin{array}{l}7.9 \\
(1.4) \\
\end{array}$ & $\begin{array}{l}9.9 \\
(1.1)\end{array}$ & $\begin{array}{l}4.6 \\
(0.7) \\
\end{array}$ & $\begin{array}{r}25.8 \\
(7.0) \\
\end{array}$ \\
\hline 1983 & $\begin{array}{c}75.4 \\
(36.1)\end{array}$ & \multicolumn{2}{|c|}{$\begin{array}{c}53.0 \\
(20.7) \\
\end{array}$} & $\begin{array}{r}41.0 \\
(15.4)\end{array}$ & $\begin{array}{c}28.6 \\
(14.3)\end{array}$ & $\begin{array}{l}8.7 \\
(1.3)\end{array}$ & $\begin{array}{l}10.4 \\
(0.9)\end{array}$ & $\begin{array}{l}4.9 \\
(1.0)\end{array}$ & $\begin{array}{l}27.1 \\
(7.0)\end{array}$ \\
\hline 1984 & $\begin{array}{r}75.0 \\
(34.4) \\
\end{array}$ & \begin{tabular}{r|}
41.6 \\
$(13.8)$ \\
\end{tabular} & $\begin{array}{l}17.6 \\
(4.5)\end{array}$ & $\begin{array}{r}42.1 \\
(15.5)\end{array}$ & $\begin{array}{c}26.3 \\
(12.3)\end{array}$ & $\begin{array}{l}7.5 \\
(1.1)\end{array}$ & $\begin{array}{l}9.7 \\
(1.0)\end{array}$ & $\begin{array}{l}5.2 \\
(0.9)\end{array}$ & $\begin{array}{r}25.7 \\
(6.5)\end{array}$ \\
\hline 1985 & $\begin{array}{r}77.2 \\
(31.4)\end{array}$ & $\begin{array}{c}43.0 \\
(14.6)\end{array}$ & $\begin{array}{c}17.1 \\
(3.5)\end{array}$ & $\begin{array}{l}42.5 \\
(16.6)\end{array}$ & $\begin{array}{c}19.8 \\
(9.0)\end{array}$ & $\begin{array}{l}10.5 \\
(0.9)\end{array}$ & $\begin{array}{l}4.8 \\
(0.5)\end{array}$ & $\begin{array}{l}5.4 \\
(0.7)\end{array}$ & $\begin{array}{l}26.4 \\
(6.6)\end{array}$ \\
\hline 1986 & $\begin{array}{l}75.0 \\
(31.6)\end{array}$ & $\begin{array}{c}44.7 \\
(14.3)\end{array}$ & $\begin{array}{l}15.3 \\
(3.3)\end{array}$ & $\begin{array}{l}42.5 \\
(15.9)\end{array}$ & $\begin{array}{c}20.5 \\
(9.9)\end{array}$ & $\begin{array}{l}10.8 \\
(0.8)\end{array}$ & $\begin{array}{l}5.2 \\
(0.3)\end{array}$ & $\begin{array}{l}5.5 \\
(0.5)\end{array}$ & $\begin{array}{c}25.3 \\
(7.1)\end{array}$ \\
\hline 1987 & $\begin{array}{c}76.4 \\
(33.0)\end{array}$ & $\begin{array}{r}42.0 \\
(13.2)\end{array}$ & $\begin{array}{l}15.5 \\
(3.0)\end{array}$ & $\begin{array}{c}46.1 \\
(19.2)\end{array}$ & $\begin{array}{c}20.4 \\
(9.0)\end{array}$ & $\begin{array}{l}9.4 \\
(0.9) \\
\end{array}$ & $\begin{array}{l}6.1 \\
(0.6) \\
\end{array}$ & $\begin{array}{l}4.7 \\
(0.9) \\
\end{array}$ & $\begin{array}{r}26.1 \\
(6.4) \\
\end{array}$ \\
\hline 1988 & $\begin{array}{c}77.1 \\
(39.3)\end{array}$ & $\begin{array}{c}45.3 \\
(15.2)\end{array}$ & $\begin{array}{c}19.1 \\
(3.3)\end{array}$ & $\begin{array}{c}50.2 \\
(21.3)\end{array}$ & $\begin{array}{c}19.2 \\
(8.6)\end{array}$ & $\begin{array}{l}10.5 \\
(1.3)\end{array}$ & $\begin{array}{l}6.3 \\
(0.4)\end{array}$ & $\begin{array}{l}5.0 \\
(0.9)\end{array}$ & $\begin{array}{l}28.0 \\
(7.4)\end{array}$ \\
\hline 1989 & $\begin{array}{l}80.5 \\
(34.2) \\
\end{array}$ & $\begin{array}{r}40.9 \\
(13.7)\end{array}$ & $\begin{array}{c}17.3 \\
(3.1)\end{array}$ & $\begin{array}{l}51.5 \\
(23.7) \\
\end{array}$ & $\begin{array}{l}17.7 \\
(7.1)\end{array}$ & $\begin{array}{l}11.1 \\
(0.9)\end{array}$ & $\begin{array}{l}7.0 \\
(0.4)\end{array}$ & $\begin{array}{l}5.7 \\
(0.6) \\
\end{array}$ & $\begin{array}{r}28.7 \\
(6.7) \\
\end{array}$ \\
\hline
\end{tabular}

Note: M.A. within 3 items. Figures in brackets show \% of S.A. of most imporant item.

Source: Central P.R. Committee of Savings 1989 
Table 2-8 Trend and prospect of labor force by industry

\begin{tabular}{|c|c|c|c|c|c|c|c|c|c|c|}
\hline & \multicolumn{5}{|c|}{ Total labor force (10 Thousand) } & \multicolumn{5}{|c|}{$\%$} \\
\hline & 1980 & 1985 & 1989 & $\begin{array}{c}1995 \\
\text { (Estimate) }\end{array}$ & $\begin{array}{c}2000 \\
\text { (Estimate) }\end{array}$ & 1980 & 1985 & 1989 & $\begin{array}{c}1995 \\
\text { (Estimate) } \\
\end{array}$ & $\begin{array}{c}2000 \\
\text { (Estimate) }\end{array}$ \\
\hline Total industry & 5,536 & 5,807 & 6.128 & 6,449 & 6.607 & 100.0 & 100.0 & 100.0 & 100.0 & 100.0 \\
\hline $\begin{array}{l}\text { Primary industry } \\
\text { (Agriculture, } \\
\text { forestry, fishery } \\
\text { and mining) }\end{array}$ & $\begin{array}{l}577 \\
577\end{array}$ & $\begin{array}{l}509 \\
509\end{array}$ & $\begin{array}{l}463 \\
463\end{array}$ & $\begin{array}{l}365 \\
365\end{array}$ & $\begin{array}{l}305 \\
305\end{array}$ & $\begin{array}{l}10.4 \\
10.4\end{array}$ & $\begin{array}{l}8.8 \\
8.8\end{array}$ & $\begin{array}{l}7.6 \\
7.6\end{array}$ & $\begin{array}{l}5.7 \\
5.7\end{array}$ & $\begin{array}{l}4.6 \\
4.6\end{array}$ \\
\hline $\begin{array}{l}\text { Secondary indus- } \\
\text { try }\end{array}$ & 1.926 & 1,992 & 2,069 & 2,176 & 2,200 & 34.8 & 34.4 & 33.8 & 33.8 & 33.3 \\
\hline Construction & 548 & 530 & 578 & 607 & 628 & 9.9 & 9.1 & 9.4 & 9.4 & 9.5 \\
\hline Manufacturing & 1.367 & 1,453 & 1,484 & 1.562 & 1.565 & 24.7 & 25.1 & 24.2 & 24.3 & 23.7 \\
\hline (Machinery) & 538 & 619 & 644 & 713 & 715 & 10.9 & 10.7 & 10.5 & 11.1 & 10.8 \\
\hline $\begin{array}{l}\text { (Other manu- } \\
\text { facturing) }\end{array}$ & 829 & 834 & 840 & 849 & 850 & 13.8 & 14.4 & 13.7 & 13.2 & 12.9 \\
\hline Tertiary industry & 3.019 & 3,283 & 3.566 & 3.908 & 4,105 & 54.5 & 56.5 & 58.2 & 60.6 & 62.0 \\
\hline $\begin{array}{l}\text { Electric, gas, } \\
\text { heat supply and } \\
\text { water }\end{array}$ & 30 & 33 & 30 & 31 & 31 & 0.5 & 0.6 & 0.5 & 0.5 & 0.5 \\
\hline $\begin{array}{l}\text { Wholesale. } \\
\text { retail trade, eat- } \\
\text { ing and drinking } \\
\text { places }\end{array}$ & 1.248 & 1,318 & 1,400 & 1.533 & 1.560 & 22.5 & 22.7 & 22.8 & 23.8 & 23.6 \\
\hline $\begin{array}{l}\text { Financing and } \\
\text { insurance, real } \\
\text { estate }\end{array}$ & 191 & 217 & 243 & 245 & 259 & 3.5 & 3.7 & 4.0 & 3.8 & 3.9 \\
\hline $\begin{array}{l}\text { Transport and } \\
\text { communication }\end{array}$ & 350 & 343 & 368 & 376 & 386 & 6.3 & 5.9 & 6.0 & 5.8 & 5.8 \\
\hline Services & 1.200 & 1.372 & 1.525 & 1,723 & 1,866 & 21.7 & 23.6 & 24.9 & 26.7 & 28.2 \\
\hline
\end{tabular}

Source : Ministry of Labor and others

Table 2-9 Problems of management of small-to-medium-sized enterprises

(\%)

\begin{tabular}{|c|c|c|c|c|c|c|c|c|c|c|c|c|}
\hline & Sluggish trode & $\begin{array}{l}\text { Low once } \\
\text { goods }\end{array}$ & Lack of ablitity & $\begin{array}{l}\text { High price of } \\
\text { raw matengis }\end{array}$ & increase & of $L$ a c K streamlino of & $\left|\begin{array}{l}\text { Oillicutity of } \\
\text { collectong bills }\end{array}\right|$ & $\begin{array}{l}\text { Difficuliny } \\
\text { financing }\end{array}$ & $\begin{array}{l}\text { of Difficulin of } \\
\text { employment }\end{array}$ & $\begin{array}{l}\text { f Environmental } \\
\text { pollution }\end{array}$ & $\begin{array}{l}\text { Difficuity of } \\
k \text { : e e p in } \\
\text { ground }\end{array}$ & Others \\
\hline $\begin{aligned} & \text { 1988. } 1 \sim 3 \\
& 4 \sim 6 \\
& 7 \sim 9 \\
& 10 \sim 12 \\
& \text { 1989. } 1 \sim 3 \\
& 4 \sim 6 \\
& 7 \sim 9 \\
& 10 \sim 12 \\
& 1990 . \quad 1 \sim 3 \\
& 4 \sim 6 \\
& 7 \sim 9\end{aligned}$ & $\begin{array}{r}23.4 \\
22.1 \\
20.4 \\
18.4 \\
16.3 \\
18.8 \\
17.2 \\
14.7 \\
14.7 \\
13.8 \\
9.9\end{array}$ & $\begin{array}{r}17.0 \\
15.7 \\
13.6 \\
12.9 \\
10.1 \\
7.2 \\
6.3 \\
5.4 \\
4.4 \\
4.1 \\
2.3\end{array}$ & $\begin{array}{l}7.4 \\
7.6 \\
8.3 \\
8.1 \\
8.5 \\
7.6 \\
6.2 \\
6.5 \\
5.7 \\
5.7 \\
5.5\end{array}$ & $\begin{array}{l}5.1 \\
4.7 \\
3.9 \\
4.0 \\
4.4 \\
5.9 \\
4.7 \\
4.8 \\
6.2 \\
4.3 \\
7.9\end{array}$ & $\begin{array}{l}13.8 \\
14.3 \\
14.0 \\
14.1 \\
14.9 \\
13.8 \\
11.5 \\
13.6 \\
17.8 \\
18.0 \\
27.6\end{array}$ & $\begin{array}{l}7.7 \\
7.6 \\
6.6 \\
6.0 \\
6.0 \\
5.7 \\
4.6 \\
4.4 \\
4.5 \\
4.6 \\
2.7\end{array}$ & $\begin{array}{l}1.2 \\
0.9 \\
1.0 \\
0.8 \\
0.5 \\
0.7 \\
0.7 \\
0.5 \\
0.7 \\
0.5 \\
0.4\end{array}$ & $\begin{array}{l}0.4 \\
0.6 \\
0.5 \\
0.5 \\
0.4 \\
0.2 \\
0.4 \\
0.4 \\
0.4 \\
0.3 \\
0.3\end{array}$ & $\begin{array}{l}12.3 \\
15.2 \\
21.1 \\
24.0 \\
29.4 \\
31.4 \\
39.6 \\
40.9 \\
37.3 \\
39.6 \\
37.3\end{array}$ & $\begin{array}{l}0.5 \\
0.6 \\
0.4 \\
0.6 \\
0.6 \\
0.5 \\
0.4 \\
0.7 \\
0.4 \\
0.5 \\
0.4\end{array}$ & \begin{tabular}{|l|}
1.5 \\
2.1 \\
1.9 \\
2.1 \\
1.6 \\
1.3 \\
1.4 \\
1.4 \\
1.4 \\
1.9 \\
1.2
\end{tabular} & $\begin{array}{l}4.7 \\
4.6 \\
3.9 \\
4.7 \\
3.9 \\
3.2 \\
3.2 \\
3.1 \\
3.1 \\
3.1 \\
2.1\end{array}$ \\
\hline
\end{tabular}

Source: Smaller Business Finance Corporation

Table 2-10 Ratio of companies with retirement age limit rule

(\%)

\begin{tabular}{|c|c|r|r|r|r|r|r|r||r|}
\hline $\begin{array}{c}\text { Size of } \\
\text { companies }\end{array}$ & Total & $\sim 54$ & 55 & $56 \sim 59$ & 60 & $61 \sim 64$ & 65 & $65 \sim$ & $60 \sim$ \\
\hline Total & 100.0 & 0.5 & 19.3 & 16.2 & 60.1 & 1.1 & 2.7 & 0.0 & 63.9 \\
$5.000 \sim$ & 100.0 & - & 4.0 & 5.3 & 89.1 & 1.2 & 0.3 & - & 90.6 \\
$1.000 \sim 4999$ & 100.0 & 0.1 & 6.2 & 9.2 & 82.8 & 0.9 & 0.7 & - & 84.4 \\
$300 \sim 999$ & 100.0 & - & 12.4 & 18.2 & 67.3 & 1.5 & 0.5 & - & 69.3 \\
$100 \sim 299$ & 100.0 & 0.3 & 14.8 & 15.4 & 65.9 & 0.8 & 2.7 & 0.0 & 69.4 \\
$30 \sim 99$ & 100.0 & 0.6 & 22.3 & 16.6 & 56.3 & 1.3 & 3.0 & - & 60.6 \\
\hline
\end{tabular}

Source : Ministry of Labor, 1990 
Table 2-11 Ratio of companies with retirement age limit of 65 and over

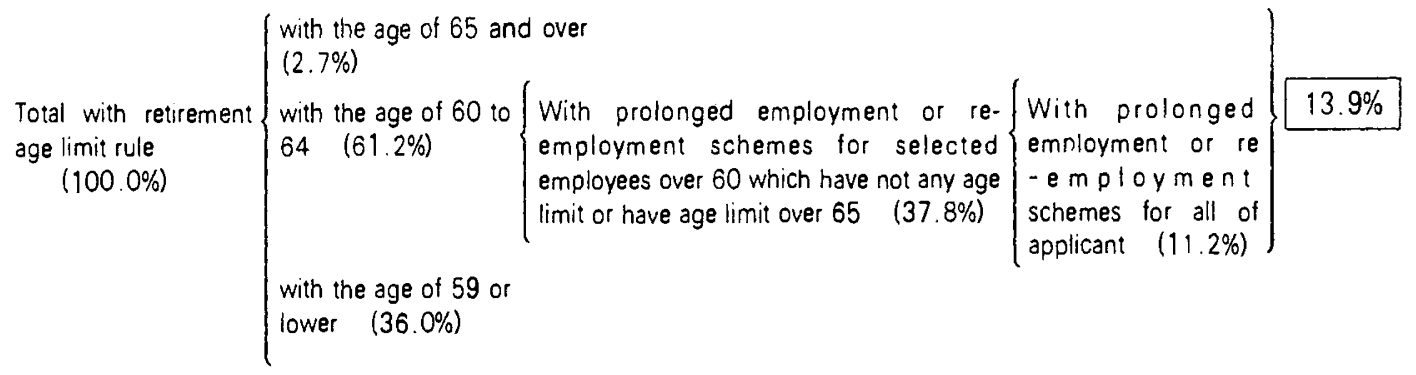

Source : Ministry of Labor, 1990

Table 2-12 Trend of aged labor force ratio by age and sex Male

\begin{tabular}{|l|r|r|r|r|r|r|r|r|r|}
\hline & \multicolumn{3}{|c|}{$55 \sim 59$} & \multicolumn{3}{c|}{$60 \sim 64$} & \multicolumn{3}{c|}{$65 \sim$} \\
\cline { 2 - 10 } & 1973 & 1979 & 1987 & 1973 & 1979 & 1987 & 1973 & 1979 & 1987 \\
\hline Japan & 92.1 & 91.9 & 91.0 & 81.0 & 77.1 & 71.7 & 46.7 & 41.1 & 35.6 \\
U.S.A. & 85.3 & 81.1 & 79.1 & 67.3 & 60.7 & 54.3 & 21.6 & 19.1 & 15.7 \\
Western Germany & 85.1 & 80.9 & 74.7 & 64.8 & 40.9 & 30.9 & 14.1 & 7.4 & 5.0 \\
France & 82.7 & 82.3 & 67.3 & 64.4 & 45.1 & 25.7 & 15.8 & 9.0 & 4.7 \\
United Kingdom & 93.0 & 90.8 & 81.0 & 82.6 & 73.0 & 53.3 & 17.5 & 10.3 & 7.9 \\
\hline
\end{tabular}

\begin{tabular}{|l|r|r|r|r|r|r|r|r|r|}
\multicolumn{1}{c|}{ Female } \\
\cline { 2 - 11 } & \multicolumn{3}{|c|}{$55 \sim 59$} & \multicolumn{3}{c|}{$60 \sim 64$} & \multicolumn{3}{c|}{$65 \sim$} \\
\cline { 2 - 10 } & 1973 & 1979 & 1987 & 1973 & 1979 & 1987 & 1973 & 1979 & 1987 \\
\hline Japan & 50.4 & 50.7 & 50.8 & 38.3 & 38.8 & 38.5 & 16.9 & 15.6 & 15.4 \\
U.S.A. & 47.7 & 48.2 & 51.9 & 33.9 & 33.5 & 32.9 & 8.4 & 7.8 & 6.9 \\
Western Germany & 36.3 & 37.3 & 36.5 & 17.6 & 11.3 & 10.4 & 5.6 & 3.2 & 2.1 \\
France & 43.1 & 45.9 & 44.6 & 33.1 & 24.0 & 18.0 & 6.8 & 4.3 & 1.9 \\
United Kingdom & 51.4 & 53.8 & 53.5 & 28.7 & 21.5 & 18.2 & 5.6 & 3.4 & 2.8 \\
\hline
\end{tabular}

Source : OECD Labor Force Statistics, 1988

Table 2-13 Responses to shortage of labor in working environment by industry

\begin{tabular}{|c|c|c|c|c|c|c|c|c|c|c|c|c|}
\hline Industry and size & Total & $\begin{array}{l}\text { Reshuthe. } \\
\text { accoptance } \\
\text { of loan } \\
\text { from other } \\
\text { comosnies }\end{array}$ & $\begin{array}{l}\text { Work on } \\
\text { holidars. } \\
\text { overnime } \\
\text { work }\end{array}$ & $\begin{array}{l}\text { Extended } \\
\text { age limit and } \\
\text { employment } \\
\text { of the reured } \\
\text { people }\end{array}$ & $\begin{array}{l}\text { To defiend } \\
\text { renrement } \\
\text { betore age } \\
\text { limit }\end{array}$ & $\begin{array}{l}\text { Re-employ- } \\
\text { ment system } \\
\text { for retred } \\
\text { female }\end{array}$ & $\begin{array}{l}\text { Increasing } \\
\text { employment } \\
\text { of non-new } \\
\text { young } \\
\text { graduates }\end{array}$ & $\begin{array}{l}\text { Tincreasing } \\
\text { employment } \\
\text { pt non-new } \\
\text { middle and dd } \\
\text { graduates }\end{array}$ & $\begin{array}{l}\text { incease of } \\
\text { tenlative. } \\
\text { seosonal and } \\
\text { part-lime } \\
\text { workers }\end{array}$ & \begin{tabular}{|l|} 
Increase of \\
nsting \\
workers \\
under \\
contract base
\end{tabular} & Others & No response \\
\hline Manulacturing & $(63) 100$ & 13 & 50 & 24 & 23 & 6 & 41 & 27 & 34 & 16 & 4 & 5 \\
\hline $1.000 \sim$ & (51) 100 & 13 & 56 & 9 & 23 & 4 & 57 & 15 & 43 & 23 & 4 & 3 \\
\hline $300 \sim 999$ & (72) 100 & 18 & 49 & $3 i$ & 26 & 7 & 35 & 29 & 33 & 16 & 1 & 3 \\
\hline $100 \sim 299$ & (74) 100 & 14 & 50 & 33 & 22 & 7 & 33 & 36 & 28 & 14 & $\vdots$ & 4 \\
\hline $30 \sim 99$ & (75) 100 & 7 & 40 & 35 & 22 & 4 & 28 & 40 & 25 & 6 & 4 & 10 \\
\hline $\begin{array}{l}\text { Consumotion } \\
\text { related industry }\end{array}$ & $(62) 100$ & 10 & 37 & 32 & 27 & 11 & 33 & 36 & 36 & 7 & 4 & 7 \\
\hline $\begin{array}{l}\text { Raw material } \\
\text { related industry }\end{array}$ & (55) 100 & 16 & 49 & 30 & 22 & 2 & 34 & 27 & 29 & 17 & 5 & 4 \\
\hline $\begin{array}{l}\text { Machinery } \\
\text { related industry }\end{array}$ & $(70) 100$ & 12 & 56 & 18 & 22 & 5 & 48 & 24 & 36 & 20 & 3 & 4 \\
\hline $\begin{array}{l}\text { Wholesale and } \\
\text { retail trade. eating } \\
\text { and drinking places }\end{array}$ & (55) 100 & 13 & 21 & 20 & 25 & 9 & 40 & 23 & 41 & 17 & 4 & 9 \\
\hline 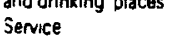 & $|(71) 100|$ & 18 & 27 & 26 & 28 & 5 & 34 & 36 & 32 & 15 & 3 & 7 \\
\hline
\end{tabular}


Table 2-14 Problems of prolonged employment for the aged of 60 to 65

\begin{tabular}{|c|c|c|c|c|c|c|c|c|}
\hline & $\begin{array}{c}\text { Total } \\
\text { companies }\end{array}$ & $\begin{array}{l}\text { Review of } \\
\text { jobs and } \\
\text { working } \\
\text { environ- } \\
\text { ment }\end{array}$ & $\begin{array}{l}\text { Review of } \\
\text { working } \\
\text { hours and } \\
\text { style }\end{array}$ & $\begin{array}{l}\text { Personal } \\
\text { manage- } \\
\text { ment like } \\
\text { status and } \\
\text { posts }\end{array}$ & $\begin{array}{l}\text { Review of } \\
\text { wage sche- } \\
\text { mes and } \\
\text { retirement } \\
\text { allowance } \\
\text { schemes }\end{array}$ & $\begin{array}{l}\text { Protection } \\
\text { against lower } \\
\text { working } \\
\text { efficiency }\end{array}$ & $\begin{array}{l}\text { Consideration } \\
\text { to health and } \\
\text { medical care }\end{array}$ & No answer \\
\hline $\begin{array}{l}\text { Number of } \\
\text { employee }\end{array}$ & 100.0 & 39.6 & 17.8 & 25.1 & 46.3 & 37.2 & 52.4 & 11.9 \\
\hline $5,000 \sim$ & 100.0 & 60.4 & 34.5 & 69.6 & 75.0 & 38.0 & 49.1 & 4.7 \\
\hline $1.000 \sim 4.999$ & 100.0 & 56.2 & 23.8 & 51.6 & 67.6 & 34.2 & 53.7 & 3.1 \\
\hline $300 \sim 999$ & 100.0 & 47.6 & 20.2 & 50.6 & 62.3 & 44.5 & 55.6 & 3.7 \\
\hline $100 \sim 299$ & 100.0 & 42.5 & 17.2 & 33.7 & 54.0 & 41.1 & 51.1 & 8.6 \\
\hline $30 \sim 99$ & 100.0 & 37.5 & 17.5 & 19.4 & 41.9 & 35.3 & 52.5 & 13.9 \\
\hline
\end{tabular}

Source: Ministry of labor, 1988

Table 2-15 Employment status by industry

$(\%)$

\begin{tabular}{|c|c|c|c|c|c|c|c|c|c|}
\hline & & Total & $\begin{array}{c}\text { Self- } \\
\text { employed }\end{array}$ & $\begin{array}{l}\text { Family } \\
\text { workers }\end{array}$ & Employees & $\begin{array}{l}\text { Regular } \\
\text { employee }\end{array}$ & Part-time & $\begin{array}{c}\text { Part-time } \\
\text { by students }\end{array}$ & Others \\
\hline \multirow{3}{*}{$\begin{array}{l}1 \\
9 \\
8 \\
7\end{array}$} & $\begin{array}{l}\text { Retail of } \\
\text { drinking and } \\
\text { eating goods }\end{array}$ & 100.0 & 22.3 & 18.5 & 59.2 & $(26.5)$ & $(21.7)$ & $(5.0)$ & (0.9) \\
\hline & $\begin{array}{l}\text { Retail of } \\
\text { others } \\
\end{array}$ & 100.0 & 18.0 & 11.1 & 71.0 & $(45.1)$ & $(11.6)$ & $(5.5)$ & $(1.6)$ \\
\hline & All industry & 100.0 & 15.0 & 8.7 & 76.3 & $(57.1)$ & $(7.7)$ & (3.1) & (3.2) \\
\hline \multirow{3}{*}{$\begin{array}{l}1 \\
9 \\
8 \\
2\end{array}$} & $\begin{array}{l}\text { Retail of } \\
\text { drinking and } \\
\text { eating goods }\end{array}$ & 100.0 & 27.3 & 23.8 & 48.9 & $(25.5)$ & \multicolumn{2}{|c|}{$(17.5)$} & $(1.1)$ \\
\hline & $\begin{array}{l}\text { Retail of } \\
\text { others }\end{array}$ & 100.0 & 19.9 & 13.0 & 67.1 & $(46.1)$ & \multicolumn{2}{|c|}{$(12.8)$} & $(1.6)$ \\
\hline & All industry & 100.0 & 16.5 & 10.1 & 73.3 & $(57.0)$ & \multicolumn{2}{|c|}{$(8.1)$} & (3.5) \\
\hline
\end{tabular}

Note: Others do not include executives in private sector who are the regular emloyee.

Source: Management and Coordination Agency 
Table 3-1 Population ratio by type of households structure

\begin{tabular}{|c|c|c|c|c|c|c|c|c|}
\hline Male & \begin{tabular}{|l|} 
One person \\
households \\
like students \\
in school \\
dormitories \\
etc.
\end{tabular} & $\begin{array}{c}\text { Other one } \\
\text { person } \\
\text { households }\end{array}$ & $\begin{array}{l}\text { A married } \\
\text { coupie only }\end{array}$ & $\begin{array}{l}\text { A married } \\
\text { couple with } \\
\text { unmarried } \\
\text { child (ren) }\end{array}$ & $\begin{array}{l}\text { Father or } \\
\text { mother with } \\
\text { unmaried } \\
\text { child(ren) }\end{array}$ & $\begin{array}{l}\text { A married } \\
\text { couple with } \\
\text { parents and } \\
\text { child (ren) }\end{array}$ & $\begin{array}{c}\text { Other } \\
\text { households }\end{array}$ & Total \\
\hline $0-4$ & 0.0 & 0.0 & 0.0 & 65.8 & 0.9 & 30.6 & 2.6 & 100.0 \\
\hline $5-9$ & 0.0 & 0.0 & 0.0 & 64.4 & 2.6 & 30.6 & 2.4 & 100.0 \\
\hline $10-14$ & 0.1 & 0.0 & 0.0 & 65.2 & 4.5 & 27.5 & 2.7 & 100.0 \\
\hline $15-19$ & 2.8 & 3.2 & 0.1 & 61.2 & 6.1 & $22 . \varepsilon$ & 3.9 & 100.0 \\
\hline $20-24$ & 8.0 & 14.5 & 2.3 & 47.3 & 5.9 & 16.7 & 5.3 & 100.0 \\
\hline $25-29$ & 5.4 & 10.9 & 9.7 & 44.4 & 5.2 & 17.6 & 6.7 & 100.0 \\
\hline $30-34$ & 1.6 & 6.7 & 7.7 & 52.3 & 4.1 & 21.8 & 5.8 & 100.0 \\
\hline $35-39$ & 0.8 & 4.7 & 4.6 & 57.8 & 3.1 & 24.5 & 4.5 & 100.0 \\
\hline $40-44$ & 0.9 & 4.1 & 4.0 & 61.9 & 2.7 & 22.9 & 3.6 & 100.0 \\
\hline $45-49$ & 1.2 & 3.5 & 5.5 & 61.2 & 2.1 & 21.8 & 4.6 & 100.0 \\
\hline $50-54$ & 1.0 & 3.1 & 13.0 & 54.0 & 1.5 & 20.1 & 7.2 & 100.0 \\
\hline $55-59$ & 0.8 & 3.1 & 24.3 & 39.4 & 1.3 & 21.4 & 9.9 & 100.0 \\
\hline $60-64$ & 0.3 & 3.3 & 34.0 & 24.8 & 1.2 & 26.5 & 9.8 & 100.0 \\
\hline $65-69$ & 0.2 & 3.9 & 37.0 & 17.3 & 1.4 & 32.0 & 8.1 & 100.0 \\
\hline $70-74$ & 0.1 & 4.1 & 37.4 & 12.4 & 1.0 & 37.8 & 7.2 & 100.0 \\
\hline $75-79$ & 0.2 & 5.3 & 30.0 & 8.2 & 1.4 & 45.3 & 9.6 & 100.0 \\
\hline $80-84$ & 0.2 & 5.6 & 23.6 & 5.0 & 2.0 & 47.9 & 15.6 & 100.0 \\
\hline $85-89$ & 0.0 & 6.9 & 16.1 & 4.1 & 1.4 & 50.0 & 21.6 & 100.0 \\
\hline $90+$ & 0.0 & 6.8 & 11.9 & 3.4 & 3.4 & 44.1 & 30.5 & 100.0 \\
\hline Unknown & 0.0 & 33.3 & 33.3 & 33.3 & 0.0 & 0.0 & 0.0 & 100.0 \\
\hline Female & \begin{tabular}{|c|} 
One person \\
households \\
like students \\
in \\
school dor- \\
mitories etc.
\end{tabular} & $\begin{array}{c}\text { Other one } \\
\text { person } \\
\text { households }\end{array}$ & $\begin{array}{l}\text { A married } \\
\text { couple only }\end{array}$ & $\begin{array}{l}\text { A married } \\
\text { couple with } \\
\text { unmarned } \\
\text { child (ren) }\end{array}$ & $\begin{array}{l}\text { Father or } \\
\text { mother with } \\
\text { unmaried } \\
\text { child (ren) }\end{array}$ & $\begin{array}{l}\text { A married } \\
\text { couple with } \\
\text { parents and } \\
\text { child (ren) }\end{array}$ & $\begin{array}{c}\text { Other } \\
\text { households }\end{array}$ & Total \\
\hline $0-4$ & 0.0 & 0.0 & 0.0 & 65.4 & 1.0 & 30.9 & 2.6 & 100.0 \\
\hline $5-9$ & 0.0 & 0.0 & 0.0 & 64.6 & 2.9 & 30.0 & 2.5 & 100.0 \\
\hline $10-14$ & 0.0 & 0.0 & 0.0 & 65.3 & 4.6 & 27.3 & 2.8 & 100.0 \\
\hline $15-19$ & 3.8 & 2.0 & 0.3 & 61.2 & 6.3 & 22.2 & 4.3 & 100.0 \\
\hline $20-24$ & 6.4 & 7.5 & 5.3 & 49.7 & 5.8 & 17.9 & 7.3 & 100.0 \\
\hline $25-29$ & 0.9 & 4.4 & 11.6 & 49.9 & 3.7 & 22.0 & 7.5 & 100.0 \\
\hline $30-34$ & 0.1 & 2.6 & 5.4 & 57.9 & 3.3 & 26.3 & 4.4 & 100.0 \\
\hline $35-39$ & 0.1 & 2.4 & 3.5 & 60.7 & 4.3 & 25.1 & 3.8 & 100.0 \\
\hline $40-44$ & 0.1 & 2.5 & 4.1 & 61.4 & 5.3 & 21.9 & 4.5 & 100.0 \\
\hline $45-49$ & 0.2 & 3.4 & 9.2 & 54.5 & 5.8 & 19.8 & 7.1 & 100.0 \\
\hline $50-54$ & 0.3 & 5.4 & 18.1 & 41.4 & 6.0 & 19.0 & 9.9 & 100.0 \\
\hline $55-59$ & 0.3 & 7.4 & 27.6 & 24.1 & 5.1 & 23.9 & 11.5 & 100.0 \\
\hline $60-64$ & 0.2 & 10.3 & 28.9 & 13.6 & 5.3 & 31.6 & 10.0 & 100.0 \\
\hline $65-69$ & 0.3 & 13.8 & 23.1 & 7.8 & 5.5 & 40.4 & 9.1 & 100.0 \\
\hline $70-74$ & 0.1 & 15.4 & 15.4 & 4.1 & 5.3 & 48.1 & 11.6 & 100.0 \\
\hline $75-79$ & 0.1 & 14.7 & 8.7 & 1.7 & 4.7 & 52.9 & 17.2 & 100.0 \\
\hline $80-84$ & 0.1 & 11.5 & 4.6 & 0.9 & 4.3 & 54.4 & 24.2 & 100.0 \\
\hline $85-89$ & 0.2 & 7.5 & 1.2 & 0.2 & 4.2 & 53.9 & 32.7 & 100.0 \\
\hline $90+$ & 0.0 & 6.3 & 1.4 & 1.4 & 3.5 & 53.5 & 34.0 & 100.0 \\
\hline Unknown & 0.0 & 0.0 & 33.3 & 0.0 & 0.0 & 33.3 & 33.3 & 100.0 \\
\hline
\end{tabular}

Source : Ministry of Health and Welfare in 1986 
Table 3-2 Ratio of companies with retirement allowance plans by type

(\%)

\begin{tabular}{|c|c|c|c|c|c|}
\hline $\begin{array}{l}\text { Size of } \\
\text { company-Year }\end{array}$ & $\begin{array}{c}\text { Company with } \\
\text { the plan }\end{array}$ & $\begin{array}{c}\text { Only lumps sum } \\
\text { payment plan }\end{array}$ & $\begin{array}{l}\text { With pension } \\
\text { payment plan }\end{array}$ & $\begin{array}{l}\text { Only pension } \\
\text { payment plan }\end{array}$ & $\begin{array}{l}\text { With lumps sum } \\
\text { payment plan }\end{array}$ \\
\hline \multicolumn{6}{|l|}{ Total } \\
\hline 1975 & {$[90.7] 100.0$} & 67.1 & 32.9 & 13.2 & 19.7 \\
\hline 1978 & {$[92.2] 100.0$} & 62.1 & 37.9 & 16.4 & 21.5 \\
\hline 1981 & {$[92.1] 100.0$} & 55.4 & 44.7 & 18.5 & 26.2 \\
\hline 1985 & {$[89.0] 100.0$} & 51.9 & 48.1 & 14.3 & 33.8 \\
\hline 1989 & {$[88.9] 100.0$} & 49.3 & 50.7 & 11.3 & 39.3 \\
\hline \multicolumn{6}{|l|}{$1,000 \sim$} \\
\hline 1975 & {$[99.8] 100.0$} & 40.2 & 59.9 & 3.4 & 56.5 \\
\hline 1978 & {$[99.9] 100.0$} & 37.7 & 62.3 & 8.5 & 53.8 \\
\hline 1981 & {$[99.6] 100.0$} & 24.6 & 75.4 & 11.5 & 63.9 \\
\hline 1985 & {$[99.9] 100.0$} & 18.1 & 81.9 & 10.1 & 71.8 \\
\hline 1989 & {$[99.5] \quad 100.0$} & 13.6 & 86.4 & 12.5 & 73.9 \\
\hline \multicolumn{6}{|l|}{$300 \sim 999$} \\
\hline 1975 & {$[99.4] 100.0$} & 50.3 & 49.7 & 9.1 & 40.6 \\
\hline 1978 & {$[99.9] \quad 100.0$} & 42.8 & 57.2 & 16.2 & 41.0 \\
\hline 1981 & {$[99.4] 100.0$} & 36.2 & 63.8 & 20.6 & 43.2 \\
\hline 1985 & {$[98.5] 100.0$} & 32.0 & 68.0 & 16.8 & 51.1 \\
\hline 1989 & {$[98.6] 100.0$} & 26.9 & 73.1 & 16.4 & 56.7 \\
\hline \multicolumn{6}{|l|}{$100 \sim 299$} \\
\hline 1975 & {$[96.6] 100.0$} & 63.0 & 37.1 & 11.3 & 25.8 \\
\hline 1978 & {$[97.3] 100.0$} & 57.1 & 42.8 & 18.3 & 24.5 \\
\hline 1981 & {$[95.9] 100.0$} & 49.2 & 50.8 & 22.2 & 28.6 \\
\hline 1985 & {$[94.9] 100.0$} & 40.4 & 59.6 & 17.0 & 42.5 \\
\hline 1989 & {$[94.1] 100.0$} & 40.8 & 59.2 & 13.0 & 46.2 \\
\hline \multicolumn{6}{|l|}{$30 \sim 99$} \\
\hline 1975 & {$[87.7] 100.0$} & 71.3 & 28.7 & 14.6 & 14.1 \\
\hline 1978 & {$[89.6] 100.0$} & 66.7 & 33.3 & 16.0 & 17.3 \\
\hline 1981 & {$[90.0] 100.0$} & 60.3 & 39.7 & 17.3 & 22.4 \\
\hline 1985 & {$[86.1] 100.0$} & 58.8 & 41.2 & 13.3 & 27.8 \\
\hline 1989 & {$[86.1] 100.0$} & 55.7 & 44.3 & 10.2 & 34.0 \\
\hline
\end{tabular}

Note : Figures in bracktes are \% in total companies Source : Ministry of Labor

Table 3-3 Trend of rate of pension payment option

Employees pension fund (Mark-up type)

\begin{tabular}{|c|c|c|c|c|c|c|c|c|c|c|c|}
\hline Fiscal year & 1977 & 1978 & 1979 & 1980 & 1981 & 1982 & 1983 & 1984 & 1985 & 1986 & 1987 \\
\hline $\begin{array}{c}\text { Rate of pension } \\
\text { payment (\%) }\end{array}$ & 34.2 & 42.0 & 43.9 & 44.0 & 48.5 & 51.9 & 50.8 & 52.4 & 56.3 & 56.3 & 60.2 \\
\hline
\end{tabular}

Source : Federation of employees' pension funds

Table 3-4 Attitude towards employment of aged in 60s by type of industries

\begin{tabular}{|l|c|c|c|c|c|c|}
\hline & (\%) \\
\hline Employed already & 66.7 & 32.1 & 48.4 & 23.1 & 49.6 & $\begin{array}{c}\text { Other } \\
\text { industries }\end{array}$ \\
\hline Employ in future & 20.7 & 54.8 & 30.6 & 16.9 & 32.8 & 37.4 \\
\hline Total & 87.4 & 86.9 & 79.0 & 39.7 & 82.4 & 80.1 \\
\hline
\end{tabular}


Table 3-5 Necessary action to employ aged in 60s

(\%)

\begin{tabular}{|c|c|c|c|c|c|c|}
\hline & Construction & $\begin{array}{l}\text { Automobile } \\
\text { relating } \\
\text { manufacturing }\end{array}$ & $\begin{array}{l}\text { Land } \\
\text { transport }\end{array}$ & $\begin{array}{l}\text { Information } \\
\text { service }\end{array}$ & Retail & $\begin{array}{l}\text { Other } \\
\text { industries }\end{array}$ \\
\hline \multirow{2}{*}{$\begin{array}{l}\text { Prolonged age limit } \\
\text { To shoren the working } \\
\text { hours }\end{array}$} & 35.0 & 24.1 & 41.7 & 30.5 & 24.8 & 32.0 \\
\hline & 17.5 & 31.3 & 28.3 & 15.3 & 38.9 & 29.3 \\
\hline Flexible working system & 40.8 & 48.2 & $\underline{50.0}$ & 37.3 & $\underline{54.9}$ & $\underline{52.4}$ \\
\hline $\begin{array}{l}\text { Revision of ability evalua- } \\
\text { ion and wage scheme }\end{array}$ & $\underline{50.8}$ & 44.6 & 26.7 & 49.2 & 37.2 & 42.3 \\
\hline $\begin{array}{l}\text { Review of retirement } \\
\text { pension scheme }\end{array}$ & 14.2 & 2.4 & 15.0 & 18.6 & 6.2 & 12.1 \\
\hline $\begin{array}{l}\text { Review of personnel } \\
\text { management }\end{array}$ & 35.8 & 8.4 & 13.3 & 18.6 & 21.2 & 15.1 \\
\hline $\begin{array}{l}\text { Review of working } \\
\text { environment }\end{array}$ & 32.5 & $\underline{77.1}$ & 43.3 & 23.7 & 40.7 & 45.9 \\
\hline $\begin{array}{l}\text { To reduce the responsible } \\
\text { tasks }\end{array}$ & 18.3 & 9.6 & 10.0 & 8.5 & 10.6 & 13.9 \\
\hline $\begin{array}{l}\text { To widen the working } \\
\text { space }\end{array}$ & 35.0 & 32.5 & 45.0 & 39.0 & 44.2 & 32.5 \\
\hline To introduce re-training & 3.3 & 6.0 & 3.3 & 13.6 & 8.0 & 8.0 \\
\hline
\end{tabular}

.Note: M.A. within 3 items

Source : Ministry of Labor

Table 3-6 Rates of job converter and its candidate

(\%)

\begin{tabular}{|c|c|c|c|c|c|c|c|}
\hline Age & 1968 & 1971 & 1974 & 1977 & 1979 & 1982 & 1987 \\
\hline $\begin{array}{l}\text { Rate of job } \\
\text { converter } \\
\text { (Total) } \\
15 \sim 24 \\
25 \sim 34 \\
35 \sim 44 \\
45 \sim 54 \\
55 \sim 59 \\
60 \sim 64 \\
65 \sim\end{array}$ & $\begin{array}{l}3.6 \\
6.8 \\
4.2 \\
2.8 \\
1.9 \\
2.2 \\
0.7\end{array}$ & $\begin{array}{l}3.7 \\
6.8 \\
4.4 \\
2.7 \\
2.0 \\
2.4 \\
0.8\end{array}$ & $\begin{array}{l}4.1 \\
7.8 \\
5.4 \\
3.0 \\
2.1 \\
2.7 \\
1.0\end{array}$ & $\begin{array}{l}2.9 \\
5.8 \\
4.0 \\
2.2 \\
1.4 \\
2.0 \\
0.6\end{array}$ & $\begin{array}{l}3.2 \\
6.9 \\
4.5 \\
2.5 \\
1.6 \\
2.2 \\
0.7\end{array}$ & $\begin{array}{l}2.6 \\
5.6 \\
3.6 \\
2.0 \\
1.4 \\
2.1 \\
1.6 \\
0.6\end{array}$ & $\begin{array}{l}4.4 \\
9.6 \\
5.8 \\
3.8 \\
2.6 \\
2.8 \\
2.8 \\
1.0\end{array}$ \\
\hline $\begin{array}{l}\text { Rate of } \\
\text { employees with } \\
\text { the desire } \\
\text { (Total) } \\
15 \sim 24 \\
25 \sim 34 \\
35 \sim 44 \\
45 \sim 54 \\
55 \sim 59 \\
60 \sim 64 \\
65 \sim\end{array}$ & $\begin{array}{l}4.5 \\
7.0 \\
5.2 \\
4.0 \\
3.1 \\
2.8 \\
1.7\end{array}$ & $\begin{array}{l}4.5 \\
7.1 \\
5.6 \\
3.9 \\
2.6 \\
2.4\end{array}$ & $\begin{array}{l}4.9 \\
8.5 \\
6.0 \\
4.5 \\
3.0\end{array}$ & $\begin{array}{r}7.6 \\
12.5 \\
9.5 \\
7.8 \\
5.0 \\
4.0\end{array}$ & $\begin{array}{r}8.7 \\
14.9 \\
10.8 \\
8.8 \\
6.2 \\
4.6 \\
1.8\end{array}$ & $\begin{array}{r}8.6 \\
15.8 \\
10.8 \\
8.8 \\
6.2 \\
4.5 \\
1.4 \\
\end{array}$ & $\begin{array}{r}9.9 \\
19.7 \\
12.8 \\
9.9 \\
7.2 \\
5.4\end{array}$ \\
\hline
\end{tabular}

Note : Rate of job converter is calculated by nos. of job converter within a year $\times 100 /$ total nos. of workers. Source: Management and Coordination Agency

Table 3-7 Attitudes towards part-time workers (retailers)

Desire to enlarge the role and responsibility of part-time or free workers in future $75.2 \%$

Desire to narrow the role and responsibility of part-time or free workers in future $\quad 2.8 \%$

Desire to remain the role and responsibility of part-time or free workers

$22.0 \%$

Source: Chogin Research Institute in 1990 
Fig. 1-1 Population percentage of persons aged 65 and over (selected countries)
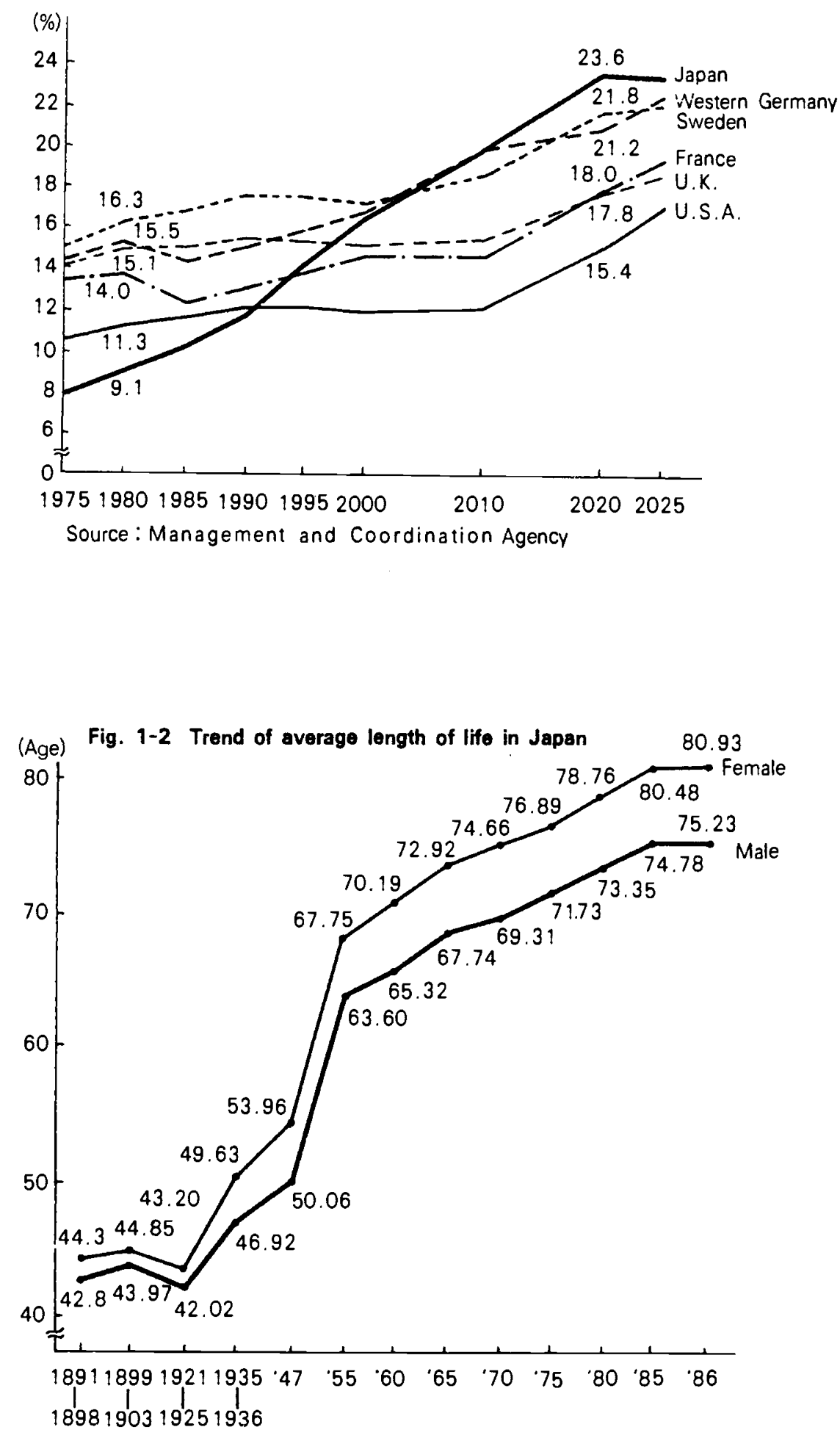

Source : Ministry of Health and Welfare 
Fig. 1-3 Average length of life in selected countries

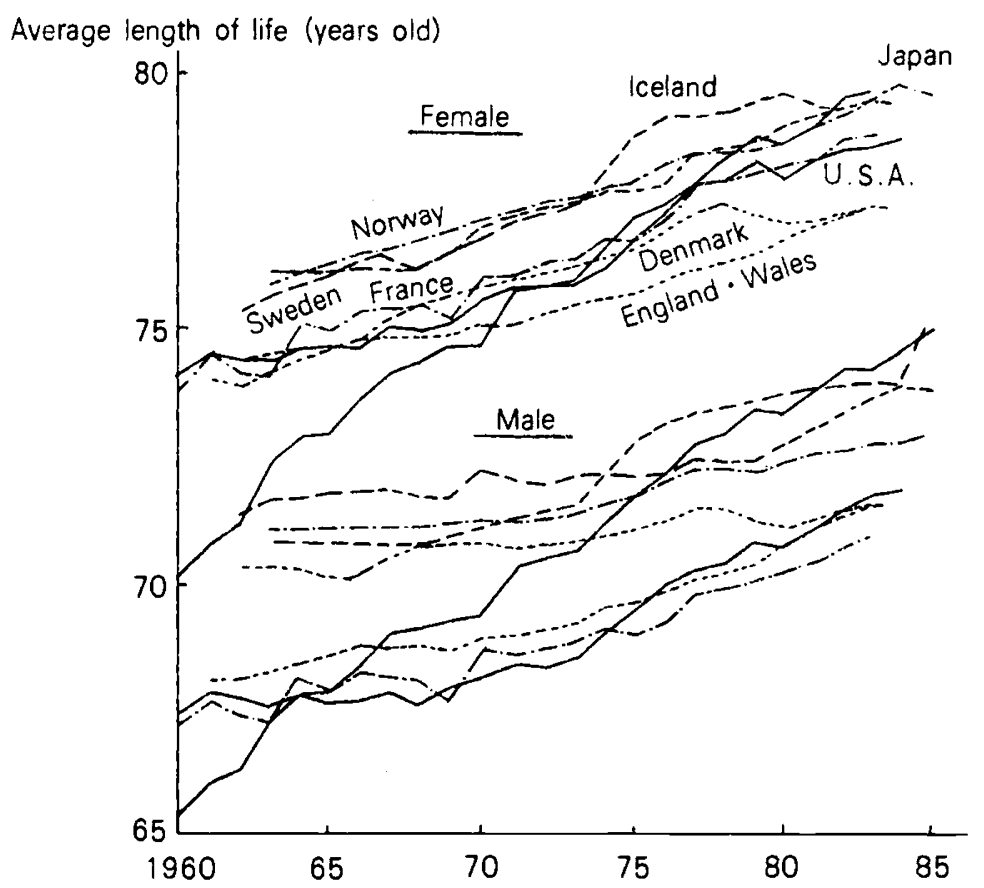

Source : Ministry of Health and Welfare

Fig. 1-4 Trends of number of live births and

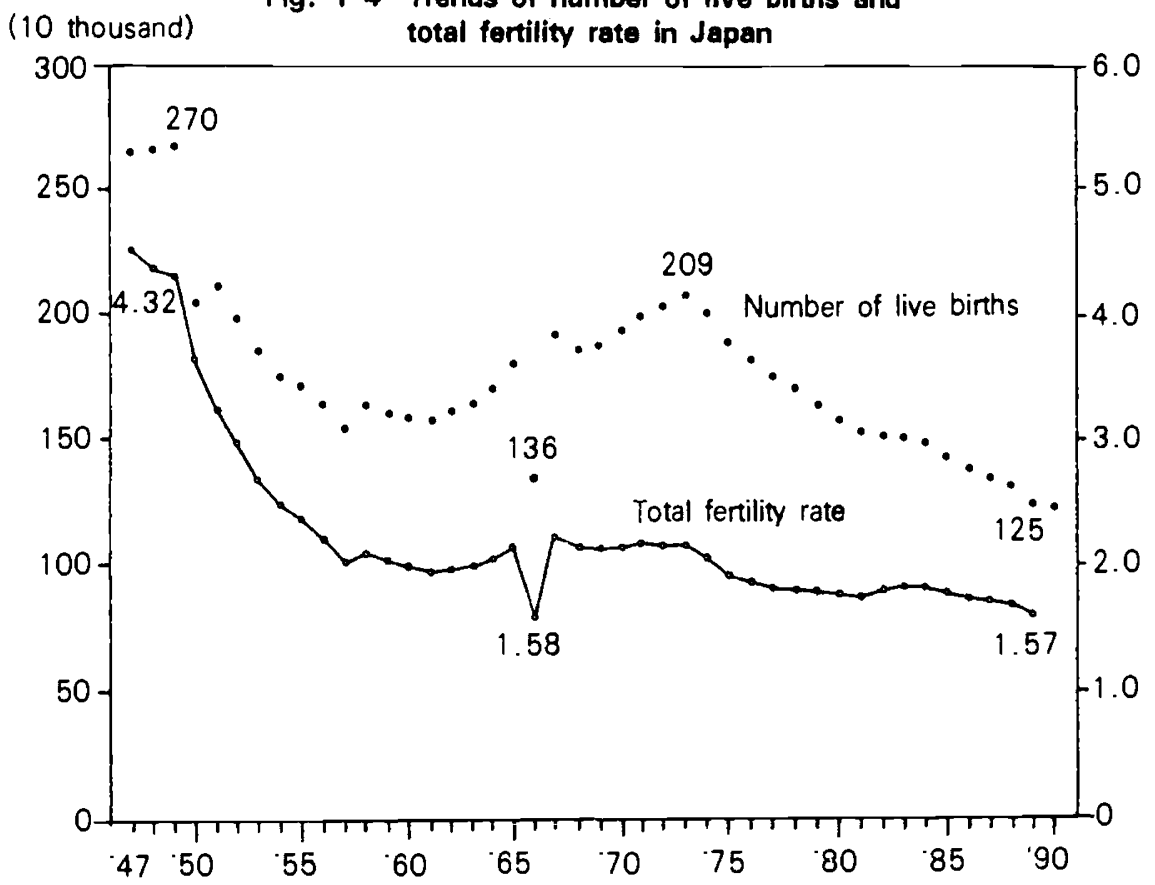

Source: Ministry of Health and Welfare 
Fig. 2-1 Concerns about pension at old age

A. Main concerns at old age

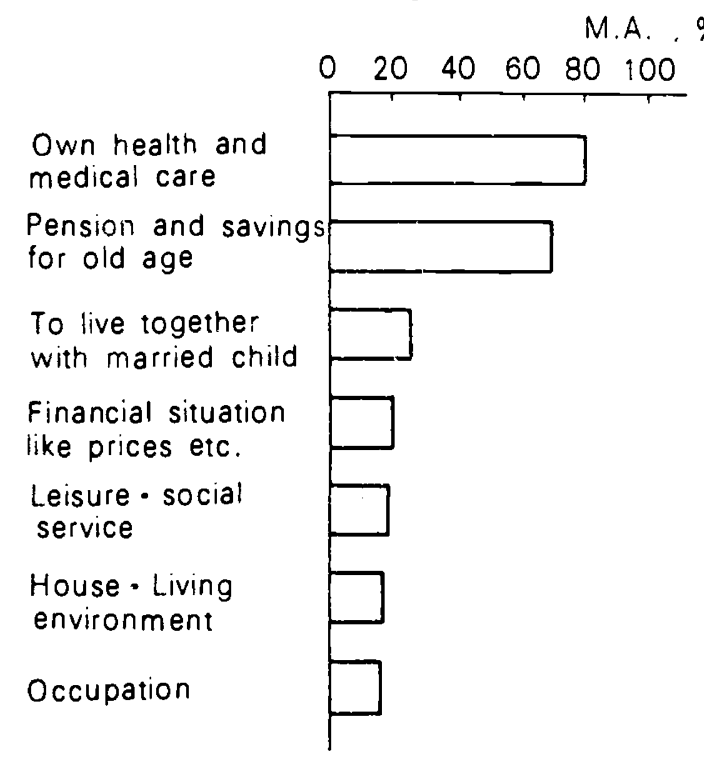

B. Main income source for living at old age M.A. \%

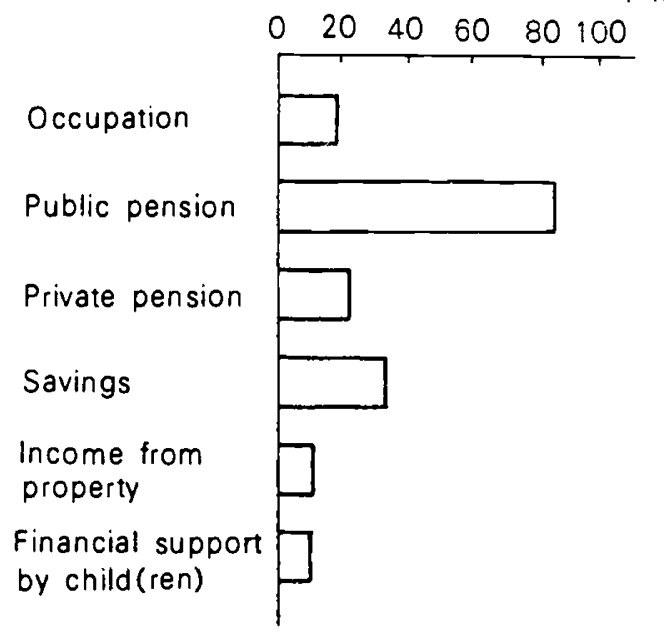

Source : National Surveys by Management and Coordination Agency, 1990 Note : $A=$ Individuals of 30 years old and over

5,000 samples (effective 3,830 )

$B=$ Individuals of $30-70$ years old

3,000 samples (effective 2.308)

Fig. 2-2 Trends in social security benefits by category

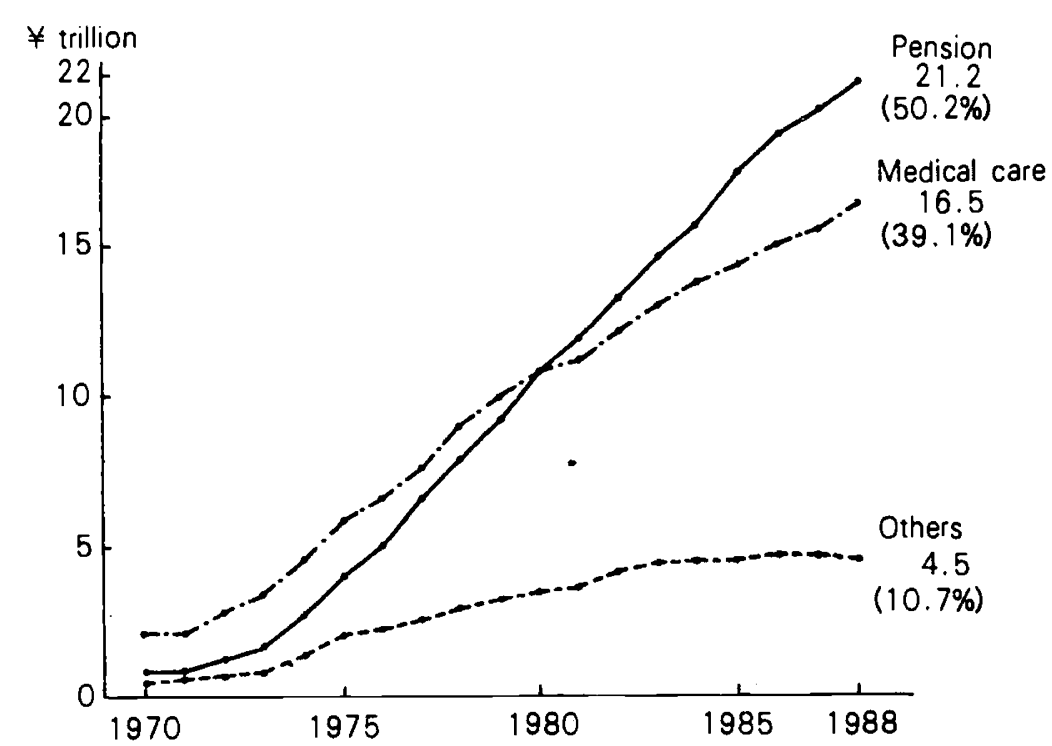

Source : Ministry of Health and Welfare. The Social Development Research Institute 
Fig. 2-3 Pension system in Japan

\begin{tabular}{|c|c|c|c|}
\hline \multirow{2}{*}{$\begin{array}{l}\text { National pension } \\
\text { funds }\end{array}$} & & Employees' pension funds & \multirow{2}{*}{$\begin{array}{l}\text { (Part of occupational } \\
\text { Rension) } \\
\text { Mutual aid pension }\end{array}$} \\
\hline & & $\begin{array}{l}\text { Employees' pesion } \\
\text { insurance }\end{array}$ & \\
\hline \multicolumn{4}{|c|}{ National pension (basic pension) } \\
\hline $\begin{array}{l}\text { Self-employed } \\
\text { household } \\
\text { Class } 1 \text { insured }\end{array}$ & Class 3 insured & $\begin{array}{l}\text { (Salaried men in private } \\
\text { sector) } \\
\text { Salaried men househol } \\
\underbrace{\text { ins }}_{\text {Class } 2}\end{array}$ & $\begin{array}{l}\text { (Official servants etc.) } \\
\vdots\end{array}$ \\
\hline
\end{tabular}

National pension funds started in April 1991

Fig. 2-4 Outlook of contribution rate increase (Employees' pension scheme, trial recalculation in 1989)

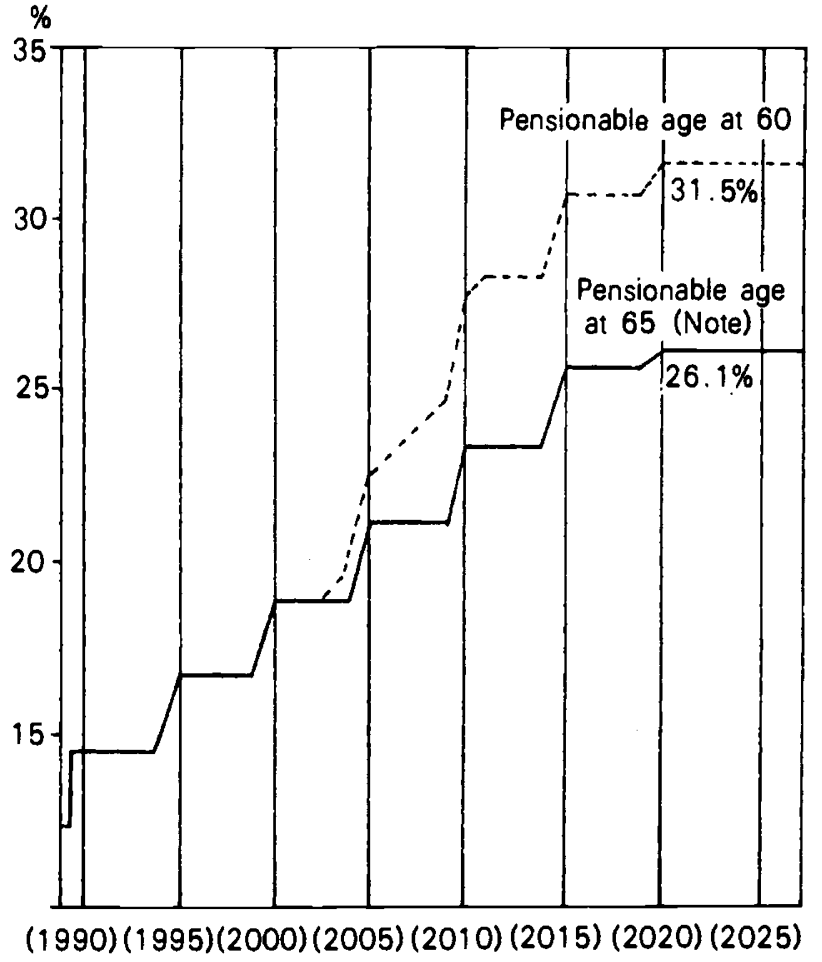

Note: Under following presumption :

Male: To put off the starting age by stages from 61 to 65 since 1998 to 2010

Female: To put off the starting age by stages from 61 to 65 since 2003 to 2015

Source : Ministry of Health and Welfare 
Fig. 2-5 Pension for salaried and seif-employed people

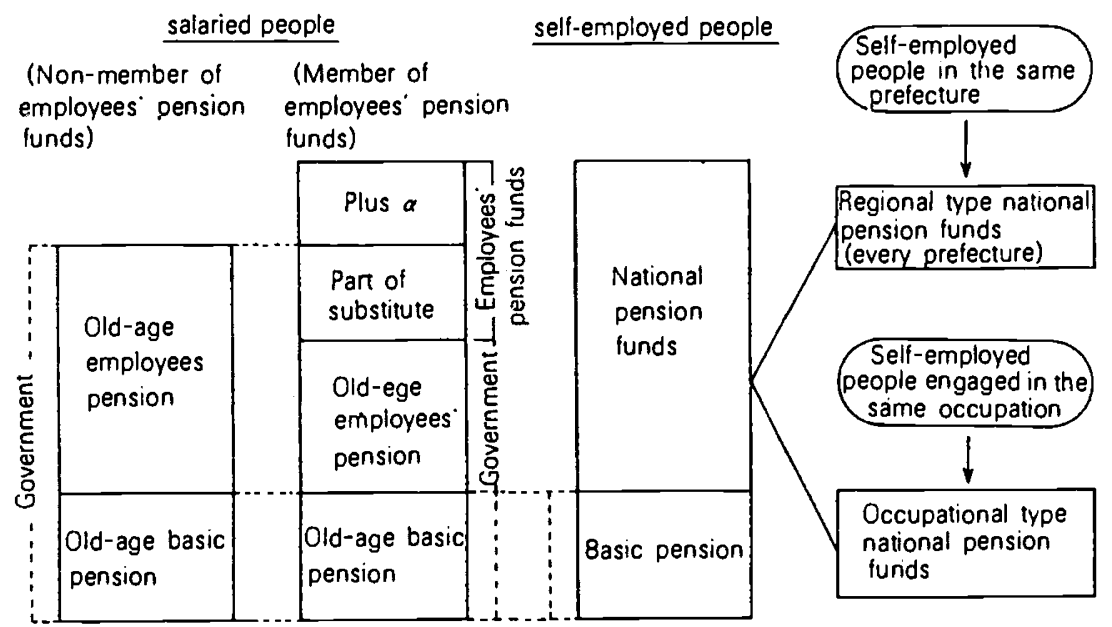

Fig. 2-6 Introduction rate of qualified retirement pension plans (Size and type of companies)

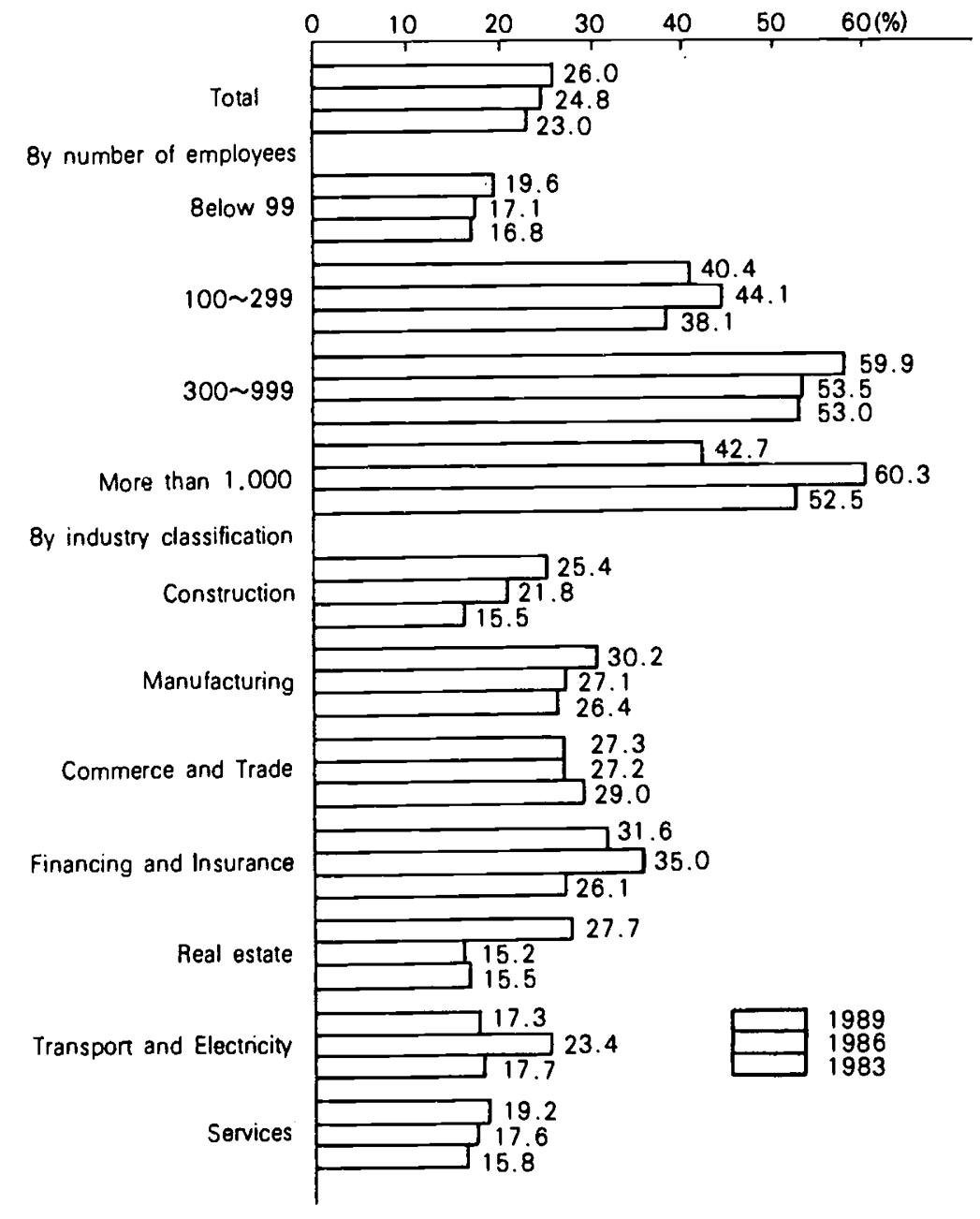

Source : Survey on employees benefit plan by JILI, 1989 
Fig. 2-7 Introduction rate of employees' pension funds (Size and type of companies)

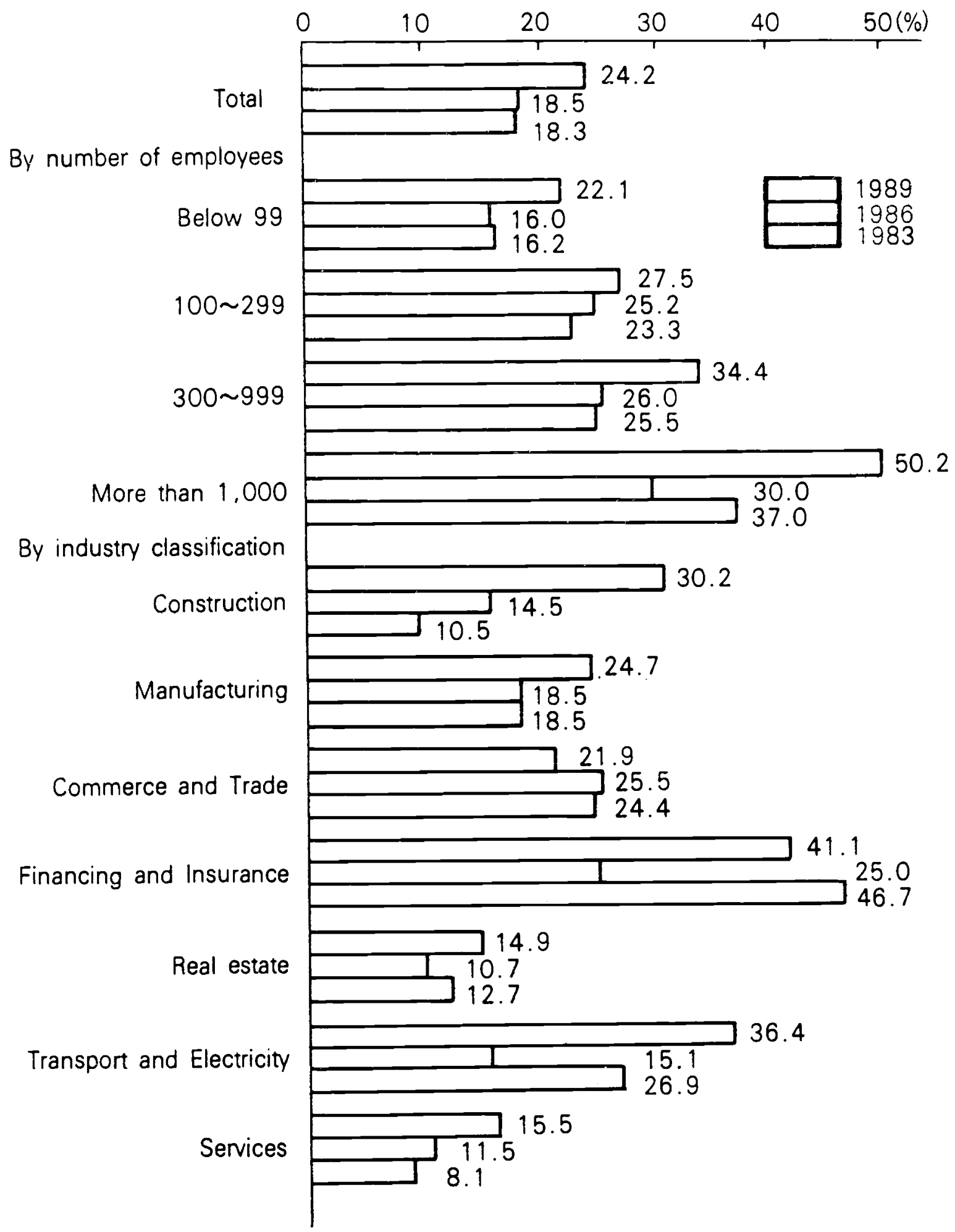

Source : Survey on employees benefit plan by JILI, 1989 
Fig. 2-8 Dissatisfied items in company life

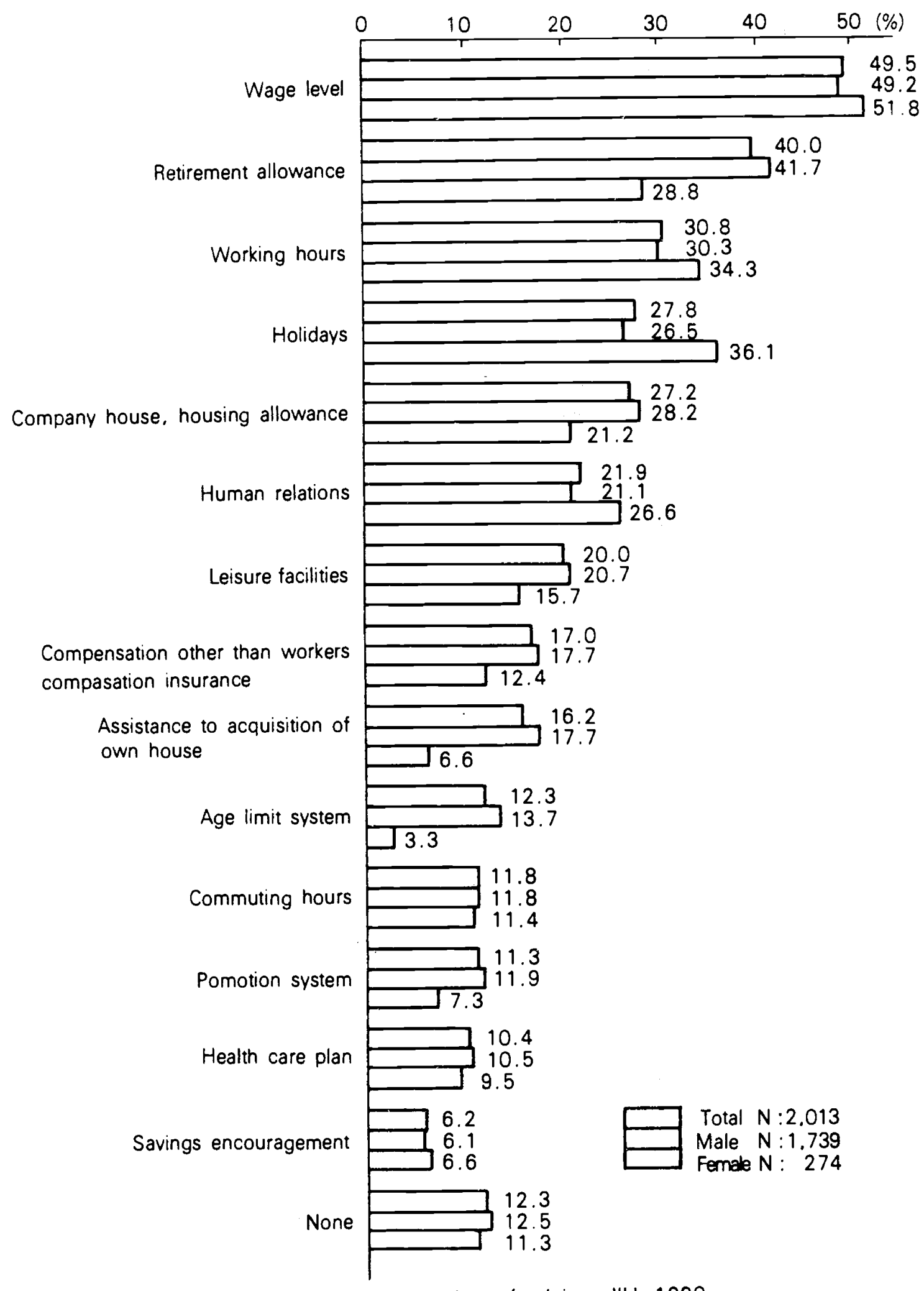

Source : Survey on employees' opinions JILI, 1990 
Fig. 2-9 Trend of individual savings rate

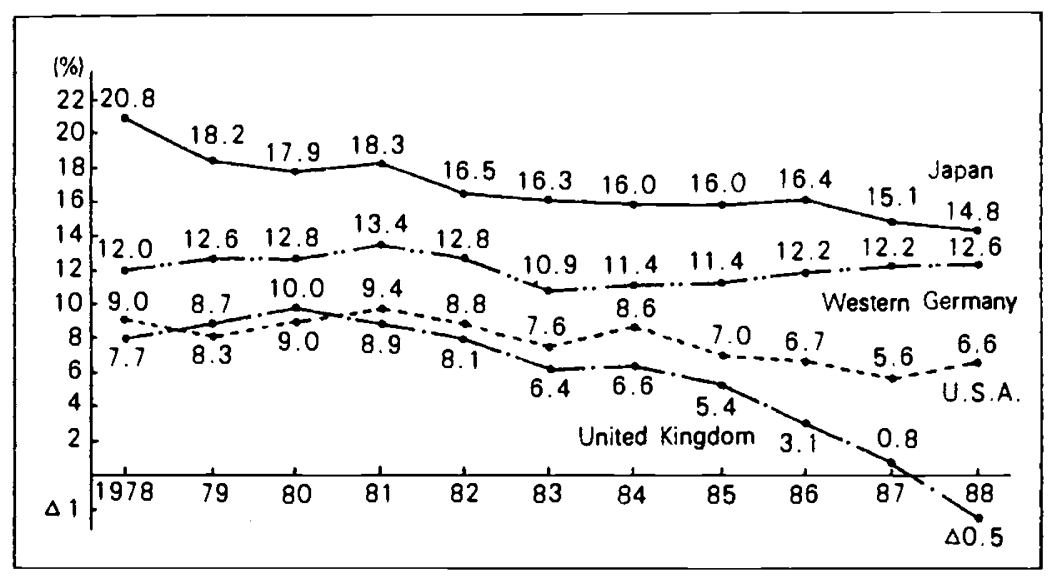

Source: Bank of Japan 1990

Fig. 2-10 Savings rate of old age householder $(\%)$ A. Japan (Average between 1987 and 1989)

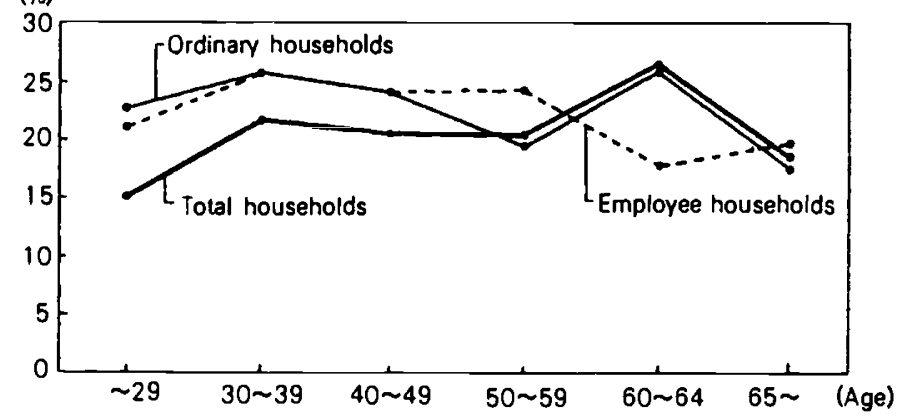

(\%) B. U.S.A. (Average between 1982 and 1984)

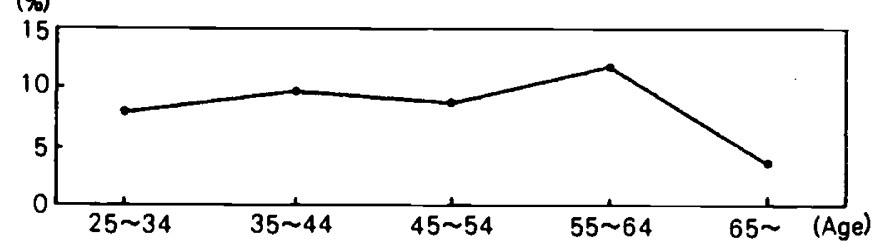

(\%) C. United Kingdom (Average between 1986 and 1988)

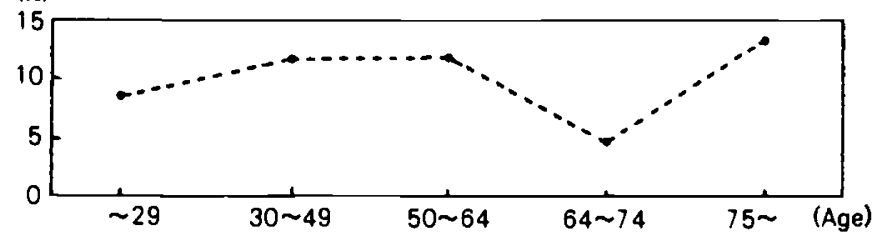

Note : Savings rate of employees household in Japan. U. S.A.and the United Kingdom are calculated by (disposable income-consumption) / disposable income. Others in Japan are calculated by (net increase of assets-net increase of debts + non-financial investment)/ annual income.

Source: Institute of household economy. U.S.A. Bureau of Labor Statistics. Department of Employment in United Kingdom 
Fig. 2-11 Trend of composition of individual life new business

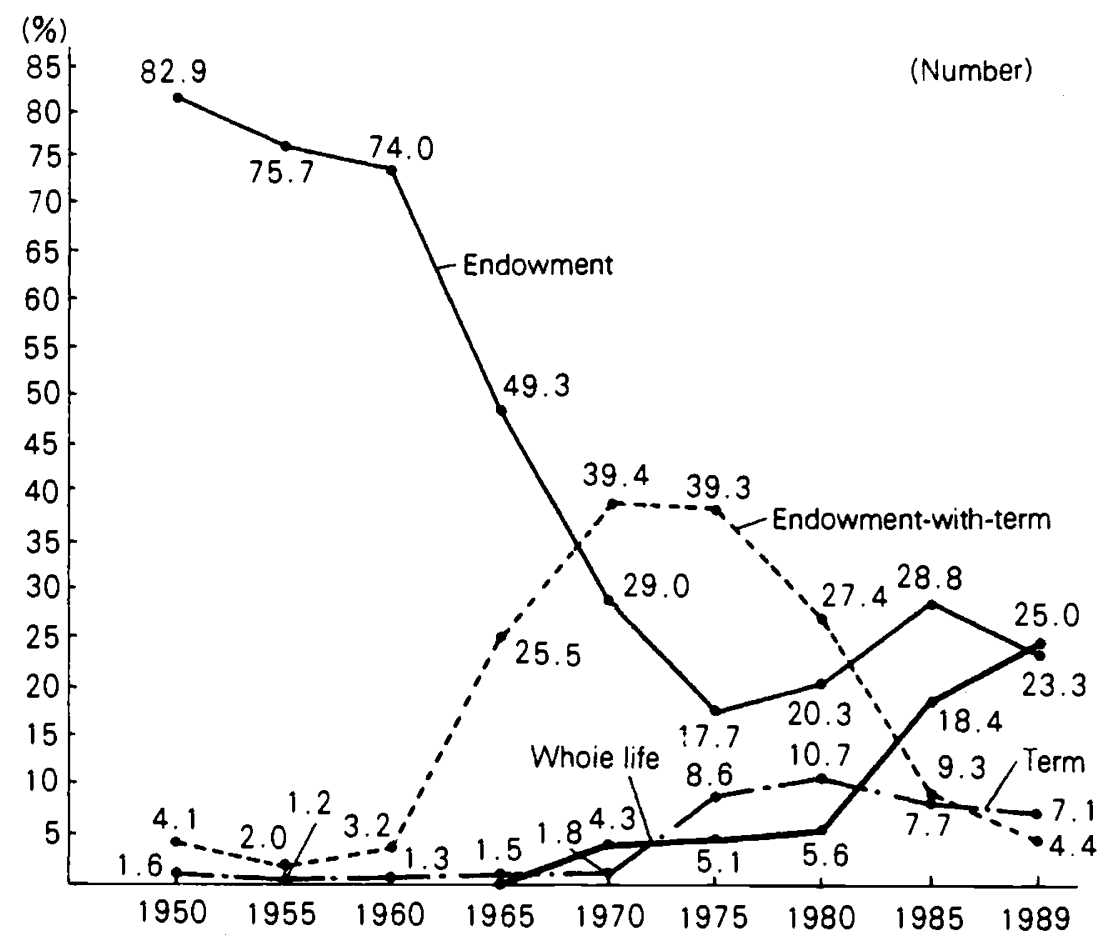

Fig. 2-12 Trend of number of individual annuities

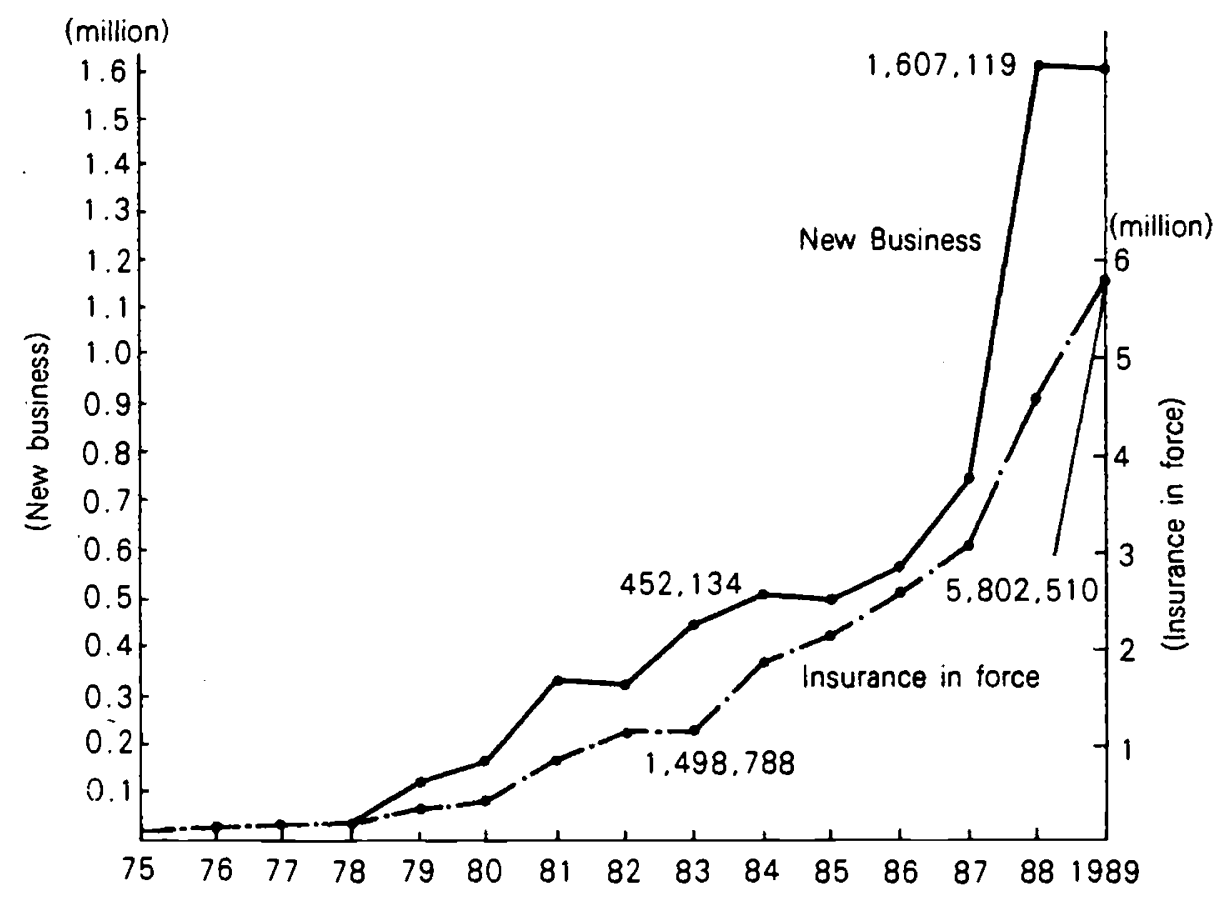


Fig. 2-13 The cityward drifting of population

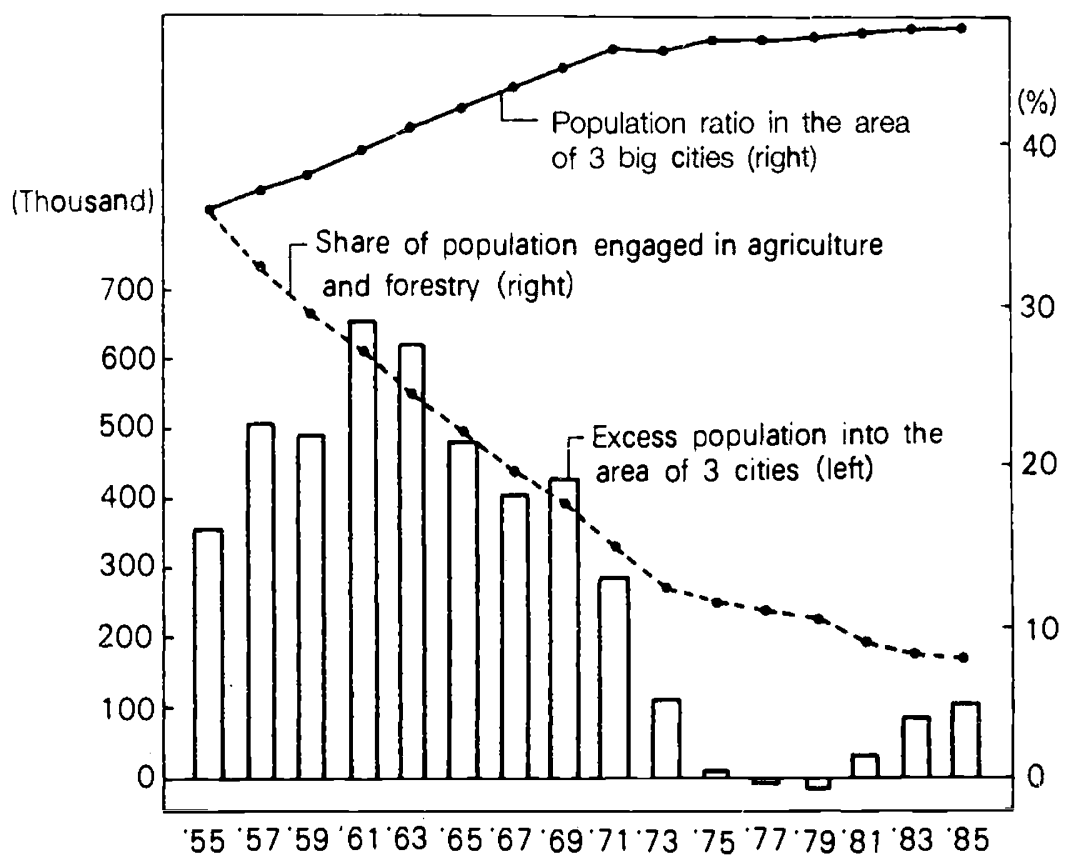

Note: The central cities of the 3 are Tokyo. Osaka and Nagoya.

Source: Management and Coordination Agency

Fig.2-14 Trend of population ratio by type of occupational status

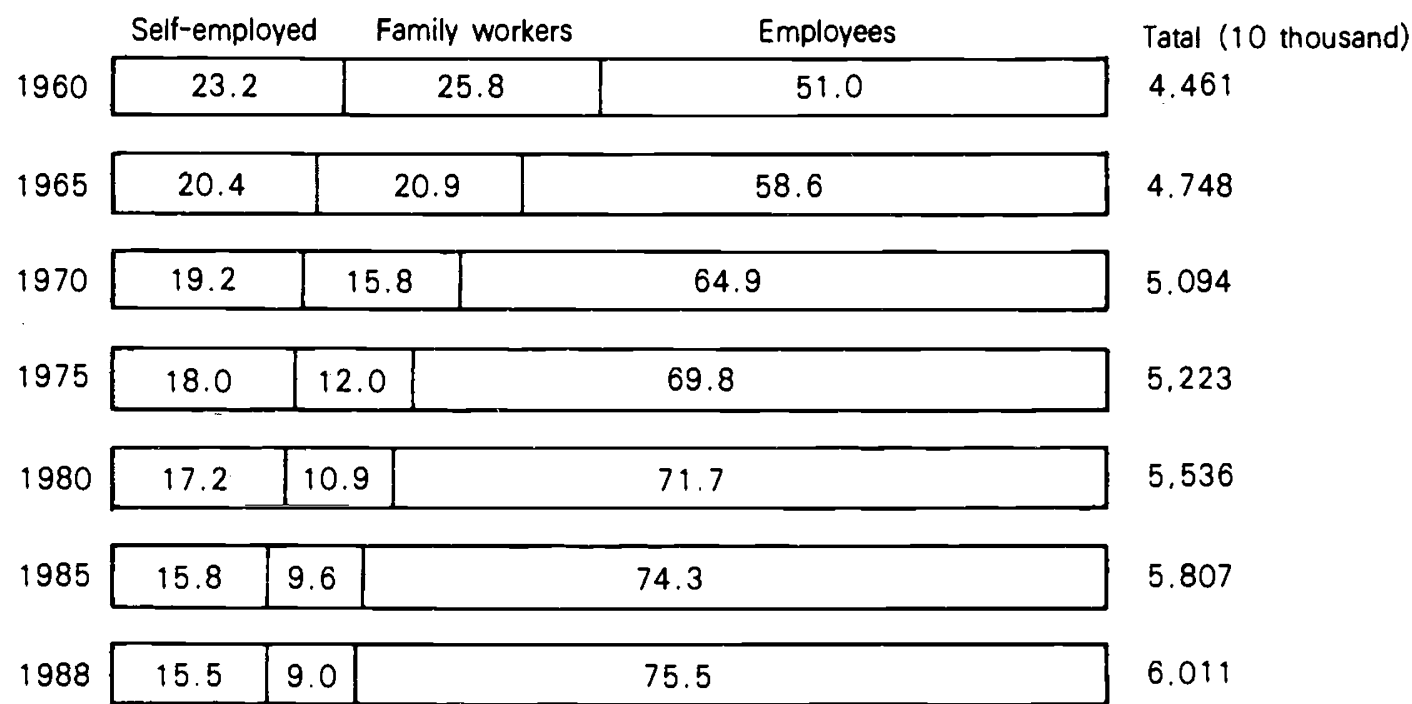

Source : Management and Coordination Agency 
Fig. 2-15 Trend of school entrance ratio into higher grade

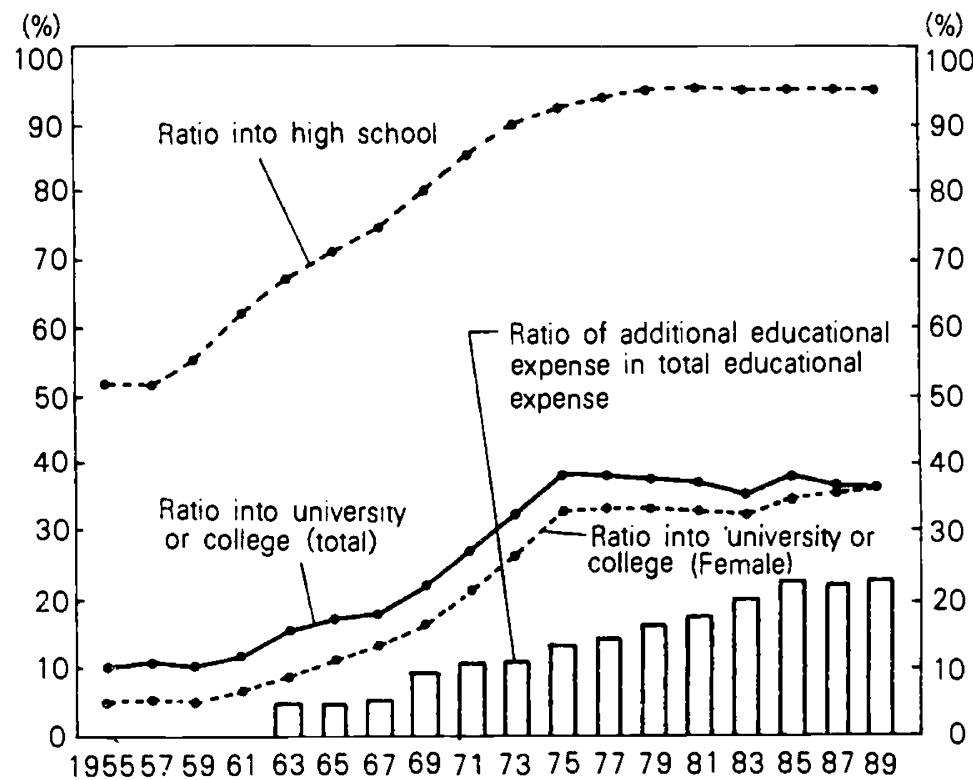

Note : Ratio into university or college is calculated by number of entrance into university or college/number of junior high school graduates in 3 years before.

Additional educational expense is the expense paid to private tutors. preparatory schools etc.

Source : The Ministry of Education. 1990

Fig. 2.16 Trend and prospect of retirement age limit by companies

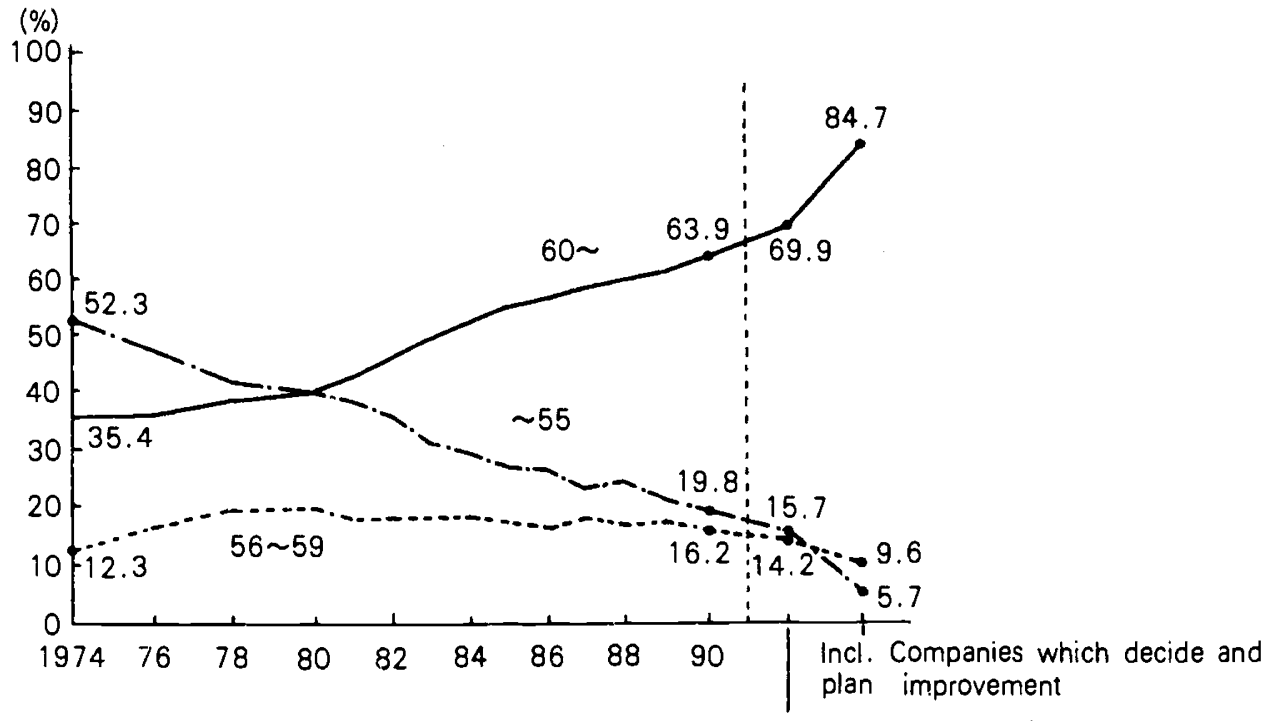

Source : Ministry of Labor Incl. companies which decide improvement 
Fig. 2-17 Desire to the company when start of pension payment is prolonged
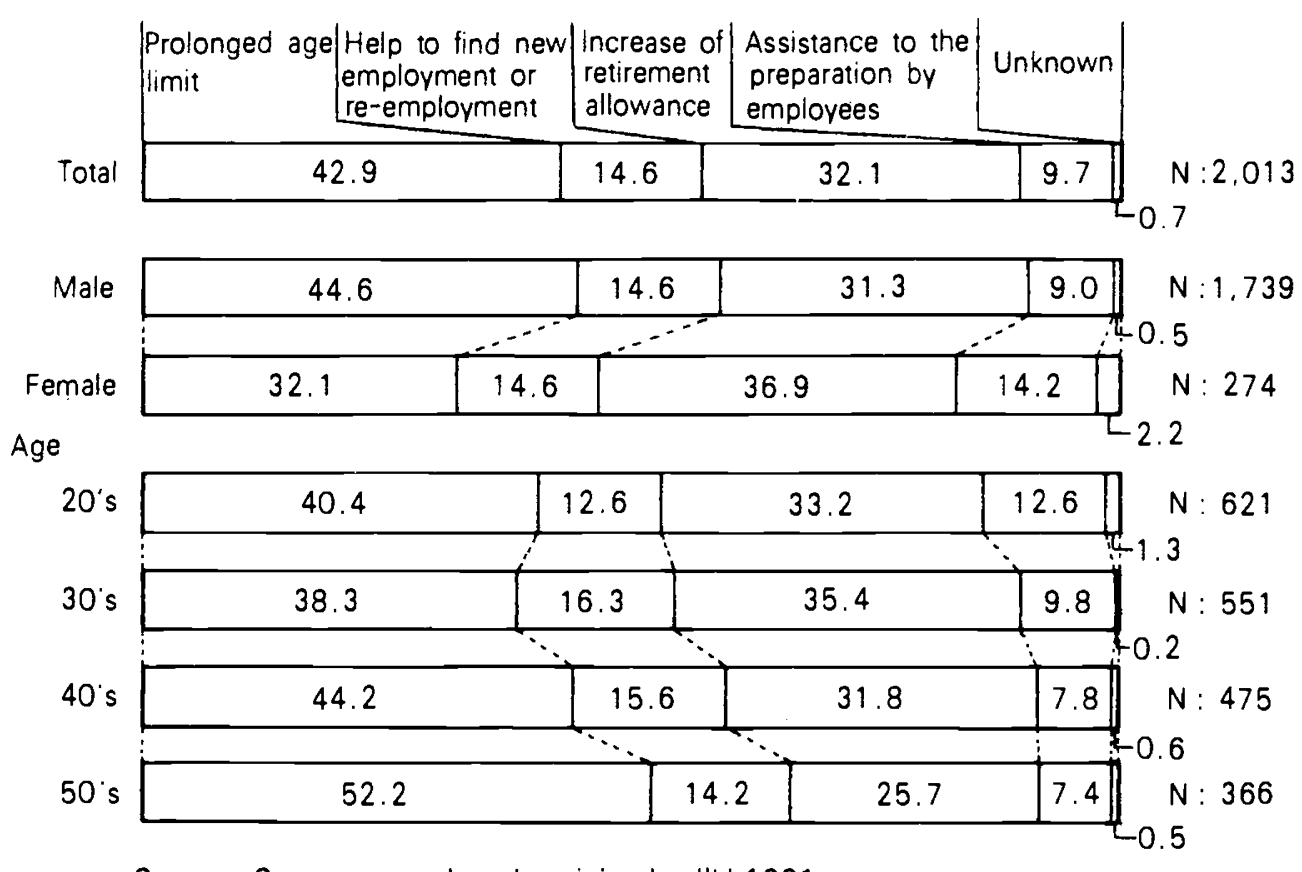

Source : Survey on employee's opinion by JILI 1991

Fig. 2-18 Attitude toward labor after retirement by age limit

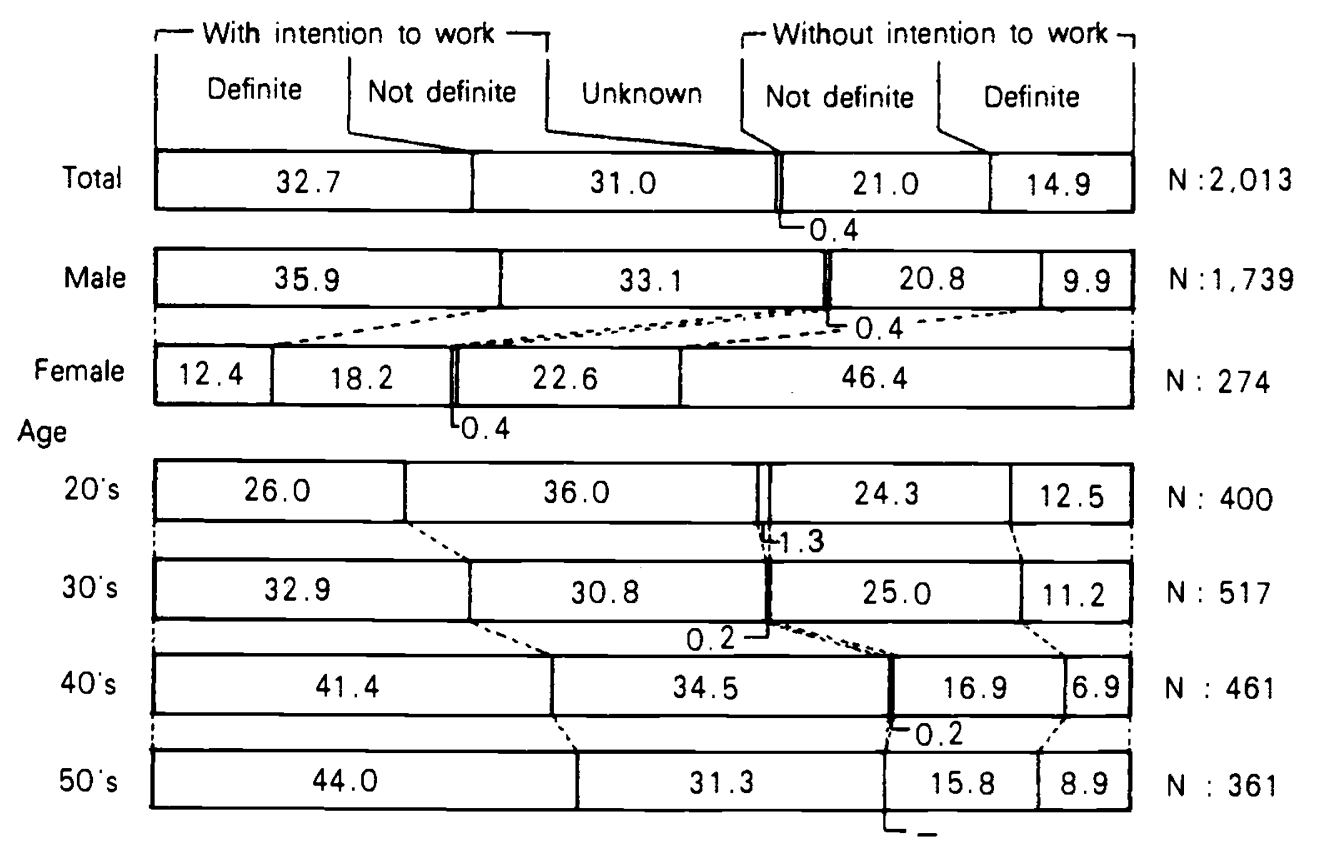

Source: Survey on employee's opinion by JILI 1991 
Fig. 2-19 Reasons for the intention to labor after retirement by age limit

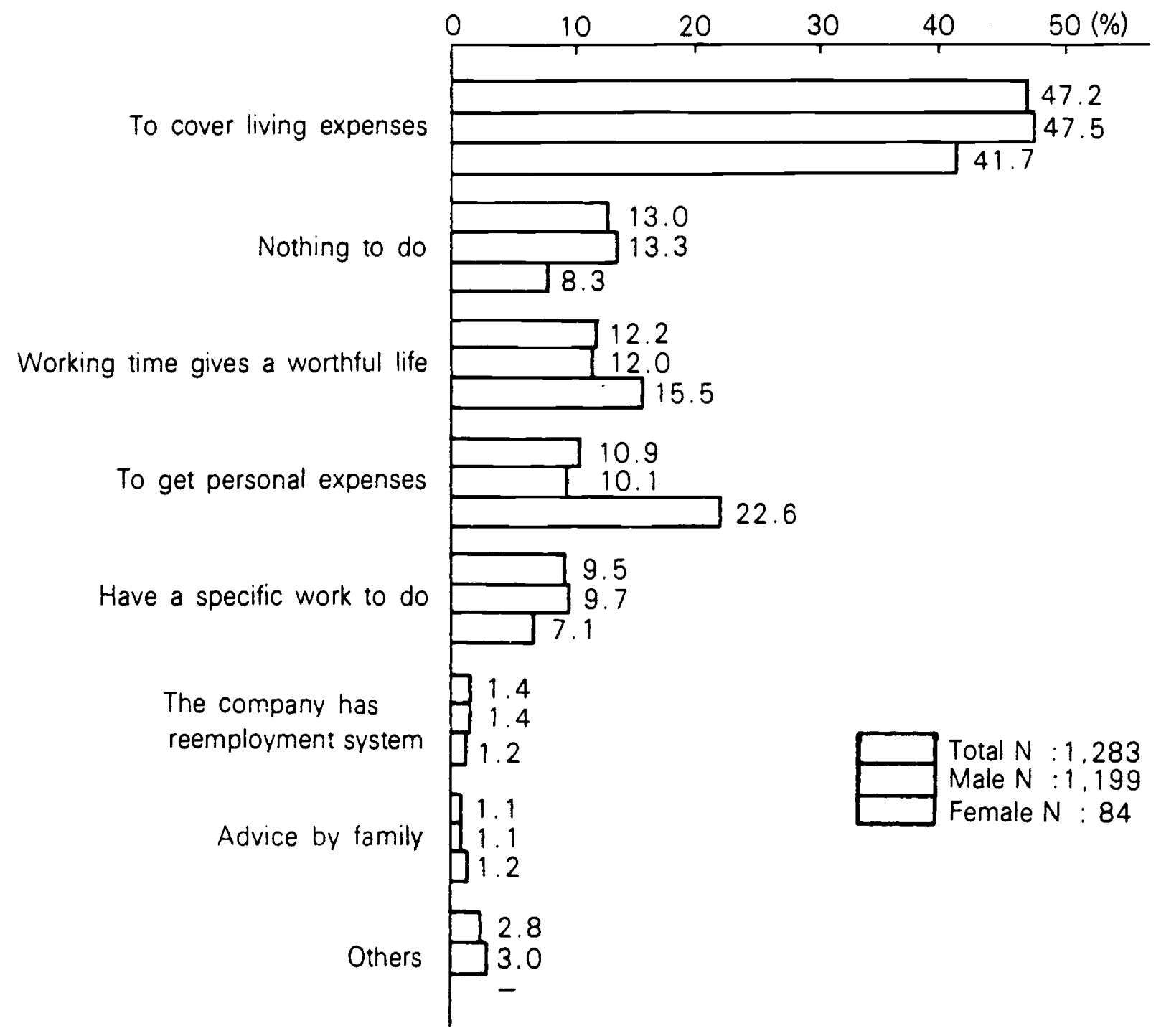

Source : Survey on employees' opinion by JILI 1991 
Fig. 3-1 Femsie labor force participation rate by age (\%)

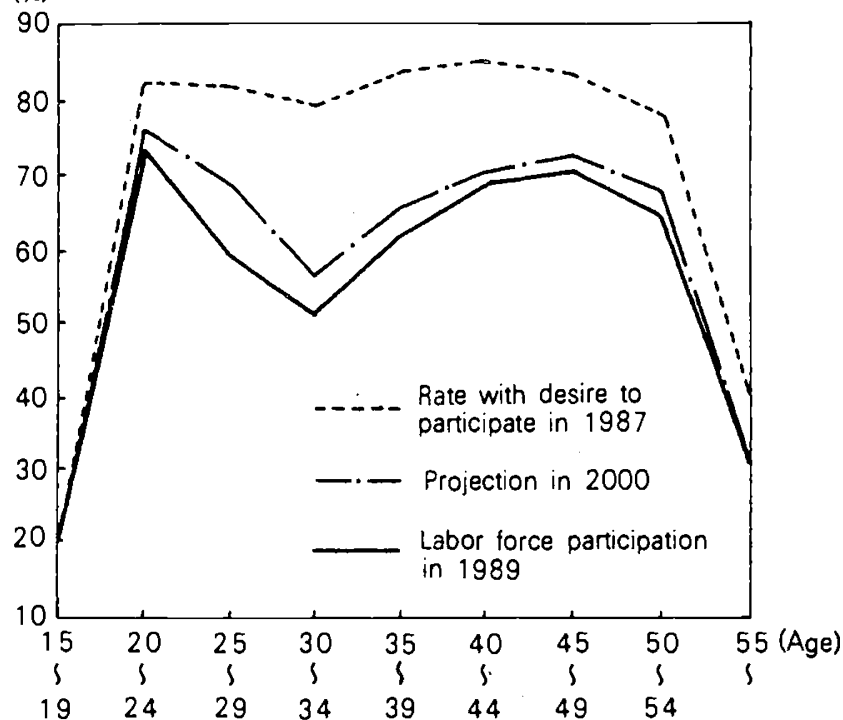

Rate with deisre to participate in 1987 is calculated by (nos. of labor at present + nos. of non-labor but with desire) $\times 100 /$ population. Others are calculated by nos. of labor/population.

Source: Management and Coordination Agency etc.

\section{Fig. 3-2 Change of working style in the past and future (Working place base)}

Past 3 years (Experience)

Decrease $\longrightarrow$ Increase

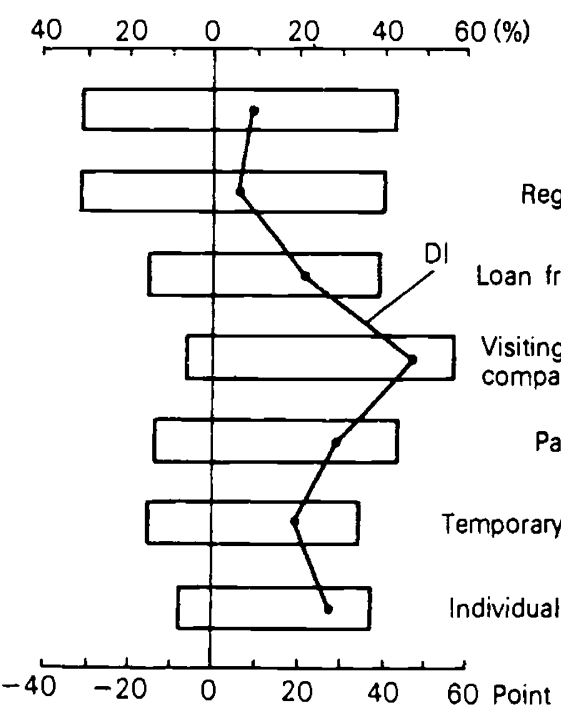

Future 3 years (Prospectation) Decrease $\longrightarrow$ Increase

All workers

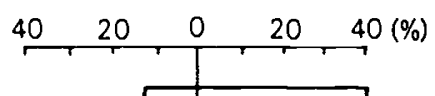

Regular employee

oan from other companies

Visiting workers from man-power mpany under contract base

Part-time workers

Note: DI shows the difference between rate of increase and that of decrease.

Source: Ministry of Labor 